\title{
CONSTITUTIONALISM IN THE SHADOW OF DOCTRINE: THE PRESIDENT'S NON-ENFORCEMENT POWER
}

\author{
DAVID BARRON*
}

\section{INTRODUCTION}

May a President refuse, on constitutional grounds, to enforce a statute that requires the firing of all HIV-positive military personnel? May a President rely upon the Fifth Amendment to bar federal prosecutors from using unwarned statements notwithstanding a federal statute that expressly validates their use? May a President invoke a constitutional norm of equality to decline to enforce a provision requiring the adoption of differential business regulations for similar professions that he "knows" to be the product of nothing more than special interest dealing?

There is a tendency among those sympathetic to the Supreme Court's rightsprotecting role to be wary of an affirmative answer to such questions. There is lurking in the background a concern that the vigorous assertion of a President's independent authority to interpret the Constitution will be destructive of the rule of law, a concern that once the Supreme Court's preeminence as constitutional adjudicator is called into question, judicially enforceable individual rights will be called into doubt. For that reason, it is perhaps not surprising that the Clinton Administration, eager to disassociate itself from its predecessors' grander claims to independent presidential interpretive authority, ${ }^{1}$ has approached with delicacy the question of the scope of the non-enforcement power.

\footnotetext{
Copyright (C) 2000 by David Barron

This article is also available at http://www.law.duke.edu/journals/63LCPBarron.

* Assistant Professor of Law, Harvard University.

The author wishes to thank Jerome Barron, Chris Desan, Richard Fallon, Jerry Frug, Elena Kagan, Juliette Kayyem, Marty Lederman, John Manning, Todd Rakoff, Laurence Tribe, and my fellow panelists on Executive Authority at the symposium. In addition, I would like to thank the Duke Program on Law and Public Policy, and in particular Walter Dellinger, Jeff Powell, and Neil Kinkopf, for organizing an exceptional event. For purposes of disclosure, I should note that I was an attorneyadvisor at the Office of Legal Counsel from 1996-99, and thus I was not at the office when it issued its non-enforcement opinion or when the Administration made its decision concerning the constitutionality of the statute requiring the dismissal of HIV-positive military personnel. In addition, I was not involved with the formulation of the Administration's position regarding the constitutionality of the provision of law that validates the use of certain unwarned statements in criminal prosecutions. Needless to say, the views expressed in this article are my own and not those of the Office of Legal Counsel.

1. See Edwin Meese, III, The Law of the Constitution, 61 TUL. L. REV. 979, 985 (1987).
} 
The Clinton Administration did not, it must be said, swing so far in the other direction that it disavowed the non-enforcement authority entirely. It rejected the position of those who contend that the executive's obligation to take care that the laws be faithfully executed deprives the President of the power to decline to enforce a statute on constitutional grounds and makes the veto power the sole means by which the President may give tangible effect to his independent constitutional views. ${ }^{2}$ Neither was the Administration willing to join, however, with those who suggest that the President's obligation to take care that the laws, of which the Constitution is the supreme one, be faithfully executed leaves the President no choice but to decline to enforce a statute whenever he believes it to be unconstitutional. ${ }^{3}$

Instead, the Clinton Administration's Office of Legal Counsel issued an important, nuanced opinion on the scope of the non-enforcement power. The opinion attempts to be respectful of the Supreme Court's "special role" in the constitutional structure, even as it is hospitable to the exercise of the executive's discretion to refuse to enforce a statute on constitutional grounds. ${ }^{4}$ The opinion attempts to perform this feat by arguing as follows. Insofar as the President intends to be a faithful constitutional actor, he may exercise the non-enforcement power. The power should generally be exercised, however, in a manner that ensures that the ultimate resolution of a statute's constitutionality will be consistent with the resolution that the Supreme Court would reach if it were presented with the question in a justiciable controversy. The President may decline to enforce a statute, the opinion therefore concludes, when it is "probable" that the Supreme Court would vindicate his independent constitutional judgment. Even then, however, the President should generally enforce statutes he believes to be unconstitutional in order to render justiciable constitutional questions that the exercise of the non-enforcement power would otherwise insulate from judi-

2. See e.g., Lear Siegler v. Lehman, 893 F.2d 205 (9th Cir. 1989) (as amended, Jan. 10, 1990) (vacated on other grounds); Christopher N. May, Presidential Defiance of "Unconstitutional" Laws: Reviving the Royal Prerogative, 21 HASTINGs CONST. L. Q. 865 (1994); see also Dawn Johnsen, Presidential Non-Enforcement of Constitutionally Objectionable Statutes, 63 Law \& Contemp. Probs. 7, 14-16 (Winter/Spring 2000) (discussing and criticizing this view).

3. See, e.g., Frank Easterbrook, Presidential Review, 40 CASE W. RES. L. REV. 905 (1989); John Harrison, The Constitutional Origins and Implications of Judicial Review, 84 U. VA. L. REV. 333 (1998); Michael Paulsen, The Most Dangerous Branch: Executive Power to Say What the Law Is, 83 GEO. L. J. 217 (1994); see also Dawn Johnsen, supra note 2, at 16-22 (discussing and criticizing this view).

4. See Presidential Authority to Decline to Execute Unconstitutional Statutes, 18 Op. Off. Legal Counsel 199, 200 (Nov. 2, 1994) ( stating that "if the president believes that the Court would sustain a particular provision as Constitutional, the President should execute the statute..." but, if he determines it to be unconstitutional, and the Court would likely agree, he has the authority not to execute the statute); see also May, supra note 2, at 991-93 (arguing that no non-enforcement power exists but suggesting that if it does, it should be limited in terms similar to those set forth in the Clinton Administration opinion).

5. 18 Op. Off. Legal Counsel at 200. 
cial review. ${ }^{6}$ For in many cases, there will be no injury sufficient to support a court challenge unless the President enforces the statute.

In her thoughtful contribution to this symposium, Professor Johnsen elaborates on this court-centered approach to presidential non-enforcement. ${ }^{7}$ She agrees that a President should generally enforce statutes that he believes to be unconstitutional. She adopts this view in significant respects because of the importance of ensuring that constitutional disputes between the branches are made justiciable. She argues, however, that the executive should then submit a brief in the ensuing litigation that lays out the executive's constitutional concerns while leaving it to Congress to provide the case in defense. It is in such briefs, she suggests, that the President may set forth his independent constitutional judgment, and it is from such briefs that the judiciary will have the benefit of the independent constitutional views of another branch. ${ }^{8}$ This approach will ensure that the Court will perform its review of the statute's constitutionality with the benefit of a full articulation of the constitutional views of the political branches. This circumstance will enhance the Court's resolution of constitutional meaning. ${ }^{9}$

This article challenges the court-centered approach to the scope of the President's non-enforcement power. It does so less because such an approach circumscribes executive authority than because, in doing so, such an approach unduly circumscribes the possible scope of constitutional limitations. In making this argument, this article emphasizes that constitutional meaning is shaped by, and should be shaped by, the institutional location of the interpreter. Such an emphasis makes it possible to critique the court-centered approach without adopting either of the more categorical responses to the non-enforcement dilemma identified above. Such an emphasis also makes it possible to discuss more generally the connection between constitutional structure and constitutional rights-enforcement that the court-centered conception of constitutionalism obscures.

The chief merits of the court-centered approach inhere in its attempt to situate constitutional interpretation within an institutional context and its concomitant rejection of the categorical notion that the President's nonenforcement power follows simply from his position as the chief executive officer. The court-centered approach points out that any such notion would permit

6. See id. at 201. The opinion goes on to explain that the President may have greater nonenforcement authority with respect to provisions that are objectionable because they intrude on the President's own constitutional powers, in part because such provisions may become justiciable only if they are disregarded. See id. It notes as well that although "some legislative encroachments on executive authority ... will not be justiciable or are for other reasons unlikely to be resolved in court," the President has the authority to decline to enforce such provisions. Id.

7. See generally Johnsen, supra note 2 .

8. See id. at 49-50.

9. See id. Professor Johnsen also explains, however, that there may be circumstances when the President should exercise his non-enforcement power even if doing so would deprive the Court of a constitutional case. She takes such instances to be exceptions to the general rule of cases that implicate the non-enforcement power. See id. at 12-13. 
constitutional interpretation to be seized by an interpreter with the institutional characteristics of the executive. Such a categorical approach would preclude other interpreters with distinct characteristics of their own (the Court and the Congress) from giving shape to constitutional meaning.

The chief flaw of the court-centered approach, however, inheres in its descriptively problematic and structurally troubling premise concerning the Supreme Court's special role in determining constitutional meaning. That premise ignores the degree to which the Supreme Court's own institutional characteristics shape its interpretations. Attention to this shaping effect undermines the notion that the Court renders final resolutions of the constitutional validity of governmental conduct when it upholds statutes against private challenges. The Court should be understood to refrain from offering such final resolutions because the political branches are themselves responsible for discerning constitutional limitations on their own conduct that no private party may be positioned fully to discern. For that reason, it is problematic to constrain the scope of the President's non-enforcement power in the name of preserving the judiciary's authority to declare the meaning of the Constitution. Such a constraint unduly circumscribes the potential scope of constitutional limitations to those capable of discernment by the Court.

To explore this line of thinking, this article contends that a President, notwithstanding that he considers himself bound by the Supreme Court's constitutional interpretations, should resolve three distinct questions in determining whether he may faithfully decline to enforce a statute by virtue of its unconstitutionality. The three questions are: (1) Is the President's substantive constitutional concern with the statute one that arises from a reasoning process that, under current doctrine, the courts would be likely to review independently if the case were justiciable? (2) Does the substantive constitutional concern with the statute arise from a reasoning process that the President, as opposed to the Congress, would be better equipped, as a matter of constitutional structure, to perform? And, finally, (3) is the reasoning process that the President would employ to resolve the second question one that the President is better positioned to perform, again taking current doctrine as a constraining guide, than either the courts or the Congress? ${ }^{10}$

The article examines these three questions in connection with the three nonenforcement cases set forth at the outset. Each of the three cases is easily resolved if the task is to ensure that the Supreme Court has an opportunity to resolve the substantive constitutional question in a case in which the President may then offer his own constitutional views to the Court. In each instance, the

10. Professor Johnsen acknowledges the basic logic of the objection that I wish to make. See Johnsen supra note 2, at 38-43. She notes that "[t] he courts at times recognize the special competencies of the political branches by deferring to their constitutional determinations in their areas of expertise and even declining to decide certain issues, for example, under the political question doctrine." Id. at 42-43. Nonetheless, Professor Johnsen argues that justiciability remain a central constraint in order to preserve debate through the judicial process, $i d$., and to ensure "respect ... [for] the constitutionally prescribed lawmaking process." Id. at 43 n.145. 
President should exercise his enforcement power in order to occasion a justiciable controversy that the Court may resolve. The analysis becomes more complicated, however, if we abandon the notion that a proper respect for the Supreme Court's special role in constitutional interpretation entails a conclusion that the Supreme Court is the preferable institution for establishing the outer bounds of constitutional limitations on governmental action.

With that assumption abandoned, it becomes clear, as Parts II and III show, that the question in all three of the non-enforcement cases set forth above reduces to whether the President or the Congress possesses greater relative interpretive authority over the type of constitutional question at issue. That secondorder, structural question is distinct from the substantive one that the Court would ordinarily be called upon to resolve in a case involving a constitutional challenge to a statute. Part IV then suggests a framework for resolving that inter-branch dispute over relative interpretive authority in a manner that roughly tracks the traditional separation of powers framework for allocating decisionmaking authority between the political branches. For example, the President has greater independent interpretive authority over questions that concern his core executive responsibilities, such as performing his duties as commander-inchief, than he does over questions that concern mere administration, such as the carrying out of general economic regulation. ${ }^{11}$

Whether the suggested structural framework for resolving such inter-branch disputes is persuasive is ultimately of secondary importance. The key point is that the constitutional dispute that must be resolved in a non-enforcement case often concerns a structural question of relative interpretive power between the legislative and executive branches rather than a substantive question of "correct" constitutional meaning. A recognition of this point undermines the seemingly appealing contention that underlies the court-centered approach to non-enforcement. For even if one grants the Court's special role in adjudicating the rights of private parties challenging the constitutionality of governmental action, it is not at all clear that we "need" the Court to resolve disputes between the political branches over their relative interpretive authority. Or, at least, as Part V explains, it is not at all clear that we "need" the Court to resolve such disputes until the branches party to them have made clear their desire for the Court's assistance. The President may, of course, seek such assistance by enforcing a statute and thereby creating a justiciable controversy. If he concludes that such assistance is not needed, however, Congress may seek such assistance through the passage of legislation that would confer causes of action upon those persons who may be deprived of the benefits of the legislation that the President has chosen on constitutional grounds not to enforce. In this way, the "need" for judicial assistance should be understood as less an a priori constraint

11. See Youngstown Sheet \& Tube Co. v. Sawyer, 343 U.S. 579, 634-35 (Jackson, J., concurring); Lawrence Lessig and Cass R. Sunstein, The President and the Administration, 94 COLUM. L. REV. 46-47 (1994). 
on the President's non-enforcement power than a judgment to be made by the political branches.

\section{II}

\section{THE DEFERENTIAL CHARACTER OF CONSTITUTIONAL DOCTRINE}

The argument for a court-centered approach to the exercise of the presidential non-enforcement power rests on a mix of procedural and substantive contentions about constitutionalism. The procedural contention is that there will be unremitting and wasteful inter-branch contentiousness in the absence of a final, authoritative arbiter of constitutional meaning. The substantive argument is that, all things considered, it is preferable to assign to the Supreme Court the role of ultimate arbiter given the match between constitutionalism's generally anti-majoritarian bent and the Court's unique insulation from majoritarian pressures. $^{12}$

If this defense of primary judicial authority to determine constitutional meaning were sound, then it would seem to follow inexorably that a President's non-enforcement power should be exercised only in order to ensure that the Supreme Court will have an opportunity to resolve the constitutionality of the statute at issue. It would be odd, after all, to conclude that, on the one hand, the constitutional structure is properly understood to privilege the interpretive products of one institution, the Supreme Court, but that, on the other, that same structure permits a distinct institution, the President, to exercise its interpretive authority in a manner that would exclude the properly privileged decisionmaker from weighing in.

The logic of the argument would seem to be sufficiently airtight as to give rise to a line of objection far more basic than the one that will be set forth here. The argument would seem to demand a challenge to the initial premise that $\mathrm{Su}-$ preme Court decisions regarding constitutional meaning should be privileged over the decisions of the other branches in any circumstance, let alone the special circumstance of the President's refusal to enforce a statute on constitutional grounds. An objection of this kind would raise deep questions of constitutional structure. It would bring to the fore what has been termed the Merryman problem. This problem concerns the degree to which the President should be bound to adhere to a judicial judgment that a favored course of governmental action would be unconstitutional. ${ }^{13}$

12. See Presidential Authority, 18 Op. Off. Legal Counsel, at 200 ("The Supreme Court plays a special role in resolving disputes about the constitutionality of enactments."); Larry Alexander \& Frederick Schauer, On Extrajudicial Constitutional Interpretation, 110 HARV. L. REV. 1359, 1362 n.12 (1997) (emphasizing the settlement function and apparently treating equivalently the duty to obey judicial decisions upholding statutes and those invalidating them); May, supra note 2, at 991-93.

13. See Ex Parte Merryman, 17 F. Cas. 144 (C.C.D. Md. 1861) (No. 9,487) (discussing President Lincoln's refusal to obey an order issuing a writ of habeas corpus); see Paulsen, supra note 3, at 278-82 (defending Lincoln's action and the broader authority of the President to disregard judicial judgments that governmental conduct is unconstitutional). 
This far more basic objection will seem powerful to some. It will respond to the sense that the court-centered argument reveals that court-centrism defines our constitutional thinking so completely as to infect even discussions of how non-judicial institutions may perform their interpretive responsibilities. Such an objection may seem to others to reflect only naiveté about how political power would likely be exercised in the absence of judicial review. It will seem to constitute a weak response to plausible contentions about the consequences of giving greater authority to the President than the court-centered approach would allow. For present purposes, however, it is unnecessary to pursue this more basic line of objection. The logic of the argument on behalf of the courtcentered approach to the exercise of the non-enforcement power need not be met so directly in order to be questioned.

Imagine, then, that a President is faced with a statute that he believes to be unconstitutional. The President should not begin his inquiry by asking whether his decision to decline to enforce the statute will deprive the Court of a justiciable case. He should instead ask whether the nature of the judgment that has led him to conclude that the statute is unconstitutional is one that a court would be likely to evaluate independently in a justiciable case. If he pursues this latter line of inquiry first, he will begin to see the problems that arise from focusing at the outset on whether a justiciable case will result from a decision not to enforce.

A President's judgment of a statute's unconstitutionality will likely rest on a mix of interdependent sub-judgments. Some will concern proper interpretations of court precedent, text, or history. Some will concern quasi-empirical determinations or normative evaluations of facts and likely results on which court precedents rest. ${ }^{14}$ Once the President focuses on the types of sub-judgments that have led him to conclude that the statute is unconstitutional, he will then have to consider the degree to which the relevant doctrine indicates that the Court would actually independently review any or all of these sub-judgments in a justiciable case challenging the statute's constitutionality. For if the Court would not undertake an independent review of these sub-judgments even in a justiciable case, then it is not at all clear that the interest in ensuring justiciability should operate to constrain the President's exercise of the non-enforcement power.

In a limited number of cases, the President may not need to think very hard on the question whether the Court would engage in independent review. The constitutional issue will, under the doctrine, be a political question or otherwise non-justiciable. It will be obvious in these instances that the Court will not have the occasion to rule on a case concerning the statute's constitutionality no matter what the President does. In such circumstances, the effect that nonenforcement would have on justiciability obviously cannot be a determining factor for the President. There is simply no way that the President can make justi-

14. See David L. Faigman, "Normative Constitutional Fact-Finding": Exploring the Empirical Component of Constitutional Interpretation, 139 U. PA. L. REV. 541, 543-44 (1991). 
ciable the dispute over the statute's constitutionality. In such cases, those who adopt the court-centered approach appear to be willing to concede that the President is not, by reason of the non-justiciable nature of the constitutional dispute, necessarily precluded from rendering a constitutional judgment regarding the statute's legality. Such a position would unduly privilege the constitutional views of the Congress over questions that are political, but not necessarily congressional. Nevertheless, it is not clear from the executive branch's writings how the President is to go about exercising his non-enforcement power in such circumstances.

For present purposes, it is important to see that these plainly political or otherwise nonjusticiable questions, in the sense that they do not admit of a justiciable resolution of the underlying, substantive constitutional questions, are not outliers. Even in cases that will clearly be justiciable if the President chooses to enforce the statute, the President is still likely to discover that the relevant doctrine is everywhere embedded with rules and tests that cast serious doubt as to whether the precise judgment that has led him to conclude that the statute is unconstitutional will be one that the court will actually independently review when the case comes before it. As a result, the President should have little reason to take solace in the possibility that a statute he believes to be unconstitutional, but nonetheless has enforced, might still be subject to private challenge before a court of law. The subsequent court challenge is likely to be decided by courts acting pursuant to doctrines and tests that are designed to ensure that judges need not interrogate the congressional conclusion that a statute is constitutional with anything approximating the rigor that the President himself felt not only entitled, but compelled, to apply.

Without belaboring the point, "[i]dentifying the 'meaning' of the Constitution is not the Court's only function. A crucial mission of the Court is to implement the Constitution successfully. In service of this mission, the Court often must craft doctrine that is driven by the Constitution, but does not reflect the Constitution's meaning precisely." ${ }^{15}$ Concerns about institutional role, institutional competence, and even problems of forging agreement among a multimember body may all result in a doctrine that not even the Court believes to represent a comprehensive, and thus preclusive, rendering of the meaning of the Constitution. The doctrine instead represents simply an effort at implementation of the Constitution by a court, positioned as it is, and structured as it is. ${ }^{16}$

That is not to say that the Supreme Court imagines the doctrine that it creates to be merely suggestive to the political branches. The doctrine is quite clearly intended to delimit the permissible scope of governmental action, and therefore to preclude governmental actors from doing certain things that they would wish to do. In this respect, the Court's doctrine does serve to deem certain governmental acts "unconstitutional" in the sense that the Court's judg(1997).

15. See Richard H. Fallon, Jr. Foreword: Implementing the Constitution, 111 HARV. L. REV. 54, 57

16. See id. 
ment amounts to a determination that it would be unlawful under the Constitution for those acts to be undertaken. Here, however, we are not concerned with the question of the role that Supreme Court doctrine should play in constraining a governmental actor's determination that a certain governmental measure is constitutional. That would be the Merryman issue. We are concerned instead with the role that Supreme Court doctrine should play in constraining a governmental actor's determination that a certain governmental measure is unconstitutional. Even if the President were to consider himself bound to obey a judicial determination that a statute is unconstitutional, in other words, it would not follow that he should understand himself to be similarly bound by a judicial determination that a statute is constitutional.

Simply put, Supreme Court doctrine will often fail to provide definitive guidance as to what a President's obligations are to obey a decision upholding the constitutionality of a statute. The Supreme Court crafts its doctrine interpreting constitutional meaning through "screens of deference." ${ }^{17}$ Its judgments upholding statutes need not be understood, therefore, to amount to determinations that these legal products are constitutional in some comprehensive or preclusive sense. Instead, court judgments often may be understood to resolve only that a private party is not in a position to have a court substitute its judgment as to the constitutionality of a governmental action for that of the political branches of the government.

The claim here, then, is not one about the necessary indeterminacy of legal meaning in a general sense. Quite the opposite. The claim is that Supreme Court doctrine is quite intelligible. What emerges from close consideration is a message that the Court's decision to uphold a statute against constitutional challenge does not constitute a final determination that would preclude other institutional actors, unburdened as they are by equivalent obligations of deference, from reaching a contrary conclusion. Or, at least, that is a message that a President could certainly divine from a doctrine that is so clearly predicated on demands of deference to political institutions.

If Supreme Court doctrine is understood in this manner, and particularly if it is understood that the Supreme Court understands its doctrine in this manner, then it will often be the case that constitutional doctrine will not of its own force provide clear direction to the President as to how he should respond to a statute he believes to be unconstitutional. The chief executive is likely to find that the doctrine that is supposed to guide him is everywhere comprised of tests and rules that compensate for or reflect the Court's own conception of the limitations of its decisional capacities. The President is likely to find everywhere in the doctrine, in other words, what might quite rightly be understood as invitations to the political branches to make decisions on their own, to do the kind of

17. See H. Jefferson Powell, The Province and Duty of the Political Departments, 65 U. CHI. L. REV. 365, 383 (1998). 
implementation of constitutional meaning that the Court will not itself perform. ${ }^{18}$

The most deferential form of the rational basis test, for example, serves as a mechanism by which the Court distinguishes between legitimate, and therefore constitutional legislation, and illegitimate, and therefore unconstitutional legislation. $^{19}$ The test asks whether there is a conceivable, rational basis on which the legislature could have found the statute to be legitimate. ${ }^{20}$ When the Court upholds a statute under the rational basis test, it need not be understood to have settled comprehensively that a particular piece of legislation is "legitimate," even though "illegitimate" legislation would quite clearly be unconstitutional. The test may rather operate to ensure only that, in the face of a private challenge, it would be rational for the government to conclude that such a policy would be legitimate. The ultimate constitutional test of legitimacy is not really met even when a statute is upheld. That is so precisely because the rational basis test serves to ensure that it need not be met in order for a statute to survive a court challenge brought by a private party.

The rational basis test, it is important to emphasize, is but the most obvious one of many similarly deferential rules that pervade modern doctrine. These rules and tests do not all take the form of generous requirements of deference to the political branches. Many of them, such as the rational basis test, take this form. Other rules, however, may take the form of what have been termed prophylactic rules. In the implementation of constitutional meaning the Court may craft rules that do not actually try to resolve what the Constitution of its own force necessarily requires, but rather are designed to "protect the underlying constitutional values" ${ }^{21}$ through a form of what may be termed overprotection. ${ }^{22}$

The classic example of such a prophylactic rule is the requirement of warnings set forth in Miranda v. Arizona. ${ }^{23}$ The Court did not contend this precise requirement was necessarily constitutionally ordained. It thought instead that this requirement was both judicially practicable to enunciate and necessary in the absence of some other equally effective, politically crafted deterrent against

18. This account of the doctrine is drawn from LAURENCE TRIBE, AMERICAN CONSTITUTIONAL LAW 949 n.121 (3d ed., 1999); Fallon, supra note 15, at 58; Michael W. McConnell, Comment, Institutions and Interpretations: A Critique of City of Boerne v. Flores, 111 HARV. L. REV. 153, 156 (1997); Lawrence G. Sager, Justice in Plain Clothes: Reflections on the Thinness of Constitution Law, 88 Nw. U. L. REV. 410 (1993) [hereinafter Sager, Justice in Plain Clothes]; Lawrence Gene Sager, Fair Measure: The Legal Status of Underenforced Constitutional Norms, 91 HARV. L. REV. 1212, 1213-20 (1978); David Strauss, The Ubiquity of Prophylactic Rules, 55 U. CHI. L. REV. 190 (1988). This conception of constitutionalism may be traced back to James B. Thayer, The Origin of and Scope of the American Doctrine of Constitutional Law, 7 HARV. L. REV. 129 (1893), although its emphasis is quite distinct. See Sager, Justice in Plain Clothes, supra, at 412-14 (discussing this connection).

19. LAUrence Tribe, AmericAn Constitutional LAW 1440 (2d ed. 1988).

20. Id. at 1443-46.

21. Michael C. Dorf, Foreword: The Limits of Socratic Deliberation, 112 HARV. L. REV. 4, 70 (1998).

22. See generally Strauss, supra note 18 (arguing that prophylactic rules are a central and necessary feature of constitutional law).

23. 384 U.S. 436 (1966). 
coercive police practices. ${ }^{24}$ Prophylactic rules are often self-consciously crafted, as the Miranda warnings were, with the idea that they are not the last word on constitutional meaning. In crafting such rules, the Court does not necessarily intend to strip political institutions of any power to substitute for them (indeed, it may implore political institutions to offer substitutions). Nor should it be understood to preclude political institutions from concluding that the Constitution compels that such rules be made even more stringent. ${ }^{25}$

In addition to rules of deference and prophylaxis, there are intermediate rules, which are at once deferential and overprotective. Examples would be the various doctrinal tests that are intended to smoke out impermissible legislative motives. Some of these tests appear on their face to be quite non-deferential, but close inspection reveals them to be the product of the demands of deference as well. These rules make up for the judiciary's own disinclination to police the motives of political actors, a disinclination that itself arises out of deference to the political branches. ${ }^{26}$ Interestingly, however, the very deference that keeps the Court from engaging in too deep an inquiry into "actual" legislative motivation produces a doctrine that is in some sense less deferential to legislators. Legislative motives can be deemed impermissible on the basis of doctrinal tests that are intended to evaluate motive without engaging in the kind of searching inquiry that might reveal the motive to have been pure. Nevertheless, while these tests of motive may rule out certain types of governmental action as impermissibly motivated, even if in some Platonic sense they are not, they do not purport to discern comprehensively all such impermissibly motivated governmental action. They, too, are a doctrinal embodiment of the Court's pervasively deferential stance. They do not operate conclusively to deem governmental motives to be pure-even in cases in which the Court cannot say with sufficient confidence that the motives in question were impure.

What these various rules have in common is that, in operation, they serve to limit the inquiries that the Court will undertake to resolve a constitutional dispute in a case brought by a private party. These rules do not, of course, confer complete freedom to the political branches. Nor are they intended to do so. Neither are they intended, however, to ensure that every constitutional case produces a judgment as to what the right construction of the Constitution is - insofar as rightness would be thought to have meaning as a concept divorced from the self-acknowledged institutional limitations from which the Court consciously constructs its doctrine. The combined effect of these rules is to leave substantial room for political actors to determine for themselves that a given course of conduct would be unconstitutional.

24. See Strauss, supra note 18, at 190-97; see also Henry B. Monaghan Foreword: Constitutional Common Law, 89 HARV. L. REV. 1, 20-26 (1975) (discussing Miranda as a prophylactic rule).

25. See Michael C. Dorf \& Charles F. Sabel, A Constitution of Democratic Experimentalism, 98 COLUM. L. REV. 267, 403 (1998) (discussing the experimental character of Miranda).

26. See Elena Kagan, Private Speech, Public Purpose: The Role of Governmental Motive in First Amendment Doctrine, 63 U. CHI. L. REV. 413, 491-505 (1996). 
The effect of doctrine's pervasively deferential character is to free political actors to give a fuller scope to constitutional limitations than could the Court, burdened as it is by the self-imposed demands of deference to political actors. The Court's doctrine embodies the screen of deference through which the Court evaluates the constitutionality of governmental action, then, not only in its willingness to uphold legislation against private challenge by applying various forms of relatively relaxed review. It embodies that deferential stance as well in its invitation to the political branches to which it defers to perform their interpretive responsibilities unburdened by the obligations that perceived demands of deference impose upon judges.

Before proceeding further, it is important to pause to acknowledge the limits of this claim. In some not insignificant number of cases, the constitutional judgment to be made will concern a matter that under current doctrine is quite clearly resolved on the basis of an interpretation of history, text, or prior precedent. The doctrine in such cases seems to exclude extrinsic considerations of the kind that a political actor such as the President would be institutionally positioned to challenge. Or, at least, in such cases, the President's disagreement with the Court's precedents will turn only on a disagreement with the doctrine's conclusion concerning the meaning of text, precedent, or history, rather than any doctrinally embedded evaluative or empirical judgment with which he is in disagreement.

In cases of this type, where the disagreement concerns a dispute over what might be termed "formal" meaning, the President's interpretive freedom is at its nadir. It is difficult to see how the President's institutional position would better equip him than the Court to make judgments of this type. ${ }^{27}$ It is important to see, however, that the instances in which questions of constitutional meaning turn on such formal legal considerations are fewer than the court-centered approach presumes. Indeed, it is a vice of the court-centered approach to nonenforcement that it tends to encourage the President to perceive the doctrinal resolution of constitutional meaning as turning on such formal legal considerations, rather than on the more practical judgments that his own institutional position well suits him to make. ${ }^{28}$

27. The analogy here is to the Court's doctrine regarding deference to executive branch interpretation of statutes, in which the Court will defer to an agency interpretation unless Congress has spoken to the precise question at issue. See Chevron U.S.A., Inc. v. Natural Resources Defense Council, Inc., 467 U.S. 837 (1984).

28. To be sure, the Court's recent decisions interpreting Section 5 of the Fourteenth Amendment do appear to be determining not only what is unconstitutional but also what is constitutional, and to be doing so in a way that is intended to preclude political actors from reaching contrary conclusions on that latter score. In both City of Boerne v. Flores, 521 U.S. 507 (1997), and Florida Prepaid Postsecondary Education Expense Board v. College Savings Bank, 119 S. Ct. 2199 (1999), for example, the Court concluded that it would be unconstitutional for Congress to exercise its Section 5 power under the Fourteenth Amendment because such exercises sought to prohibit state conduct that the Court had deemed "constitutional." The consequence of this judgment, in City of Boerne, was to render unconstitutional the Religious Freedom Restoration Act, which Congress enacted in order to enforce the Free Exercise Clause as incorporated by the Fourteenth Amendment. In College Savings Bank, the consequence of this judgment was to render unconstitutional the Patent and Plant Variety Protection Rem- 
It should be acknowledged that there is one area of doctrine in which the Court's decision to uphold legislation is clearly intended to be preclusive of the President's interpretive authority. All judicial resolutions on the merits of separation of powers cases involving the President, as well as all judicial resolutions on the merits of claims of executive privilege or immunity, have this preclusive character. In upholding a statute that arguably intrudes on executive authority, such as the statute at issue in Morrison v. Olson, ${ }^{29}$ or rejecting a claim of executive privilege, as in United States $v$. Nixon, ${ }^{30}$ the Court is necessarily establishing the degree to which the President may deem actions by a competing institutional actor to be unconstitutional-and it is resolving the issue on this score against the President.

For now, it suffices to note that outside this special context, the Court's judgments upholding federal legislation need not be understood to address the scope of the President's authority to interpret the Constitution in a manner that would render governmental action unconstitutional. These judgments are instead the products of a doctrine that is designed to evaluate the freedom of action of the federal government as such. They do not address the relative constitutional interpretive authority of the political branches of the federal government with respect to each other.

The institutional limitations that inspire the Court to create a doctrine that has this character (or that inspire a President to read the doctrine so as to give it this character) need not rest on the ground that the Court is institutionally in-

edy Clarification Act, which Congress enacted in order enforce the Due Process Clause. These cases make it clear that the Court is not beyond enunciating a preclusive constitutional doctrine. If the Court were to hold that the President did not possess a power to decline to enforce on constitutional grounds a statute that it had upheld against private challenge, nothing in the account given here would provide a direct line of argument in favor of the President's assertion of non-enforcement power notwithstanding a judicial precedent directly denying that power's existence. The account offered here does suggest, however, that the Court's doctrine generally tilts very much against preclusion.

Indeed, it is not clear that even the recent Section 5 cases deem certain conduct to be constitutional in a sense that would have preclusive force against political actors generally. In City of Boerne, the Court purported to rest its decision not only on a construction of the word "enforce" in Section 5 of the Fourteenth Amendment, but also on more general notions of the distinction between the role of the Court as constitutional interpreter and the role of the Congress as legislative actor. See City of Boerne, 521 U.S. at 536. The citations to Marbury v. Madison, 5 U.S. 137 (1803), and the concerns about the legislature intruding upon the Court's sphere of action, however, are absent from the more recent decision in College Savings Bank, which couches its holding almost entirely on a relatively strict construction of the meaning and inherent limitations in the word "enforce." $119 \mathrm{~S}$. Ct. at 2205. Those limitations seem to emanate more from concerns of federalism, and the need to place limitations on the legislative authority of the federal government to intrude on state affairs, than on any more abstract assertions about the exclusive, and thus preclusive, authority of the Court to divine constitutional limitations. See College Savings Bank, 119 S. Ct. at 2206-10. In this respect, the recent Section 5 cases may comport with the account of doctrine offered above. They do less to vest the divination of constitutional meaning in the federal courts than to wrest its divination from Congress for the benefit of the States. To read them more broadly is not to demonstrate one's respect for the Court. It would instead be to take a position with respect to constitutional structure, and the process by which constitutional limitations may take shape, that may not even be the Court's own.

29. 487 U.S. 654 (1988).

30. 418 U.S. 683 (1974). 
competent in the bureaucratic sense to take on a more expansive interpretive role. It is not as if the Court must settle on these non-preclusive doctrines solely because it lacks the technical capability to do the evaluative work that its doctrinal tests avoid. Maybe the Court could do such evaluative work and maybe it could not. Instead, the Court may be understood to opt for, and should be encouraged to opt for, tests that have this non-preclusive character because of the structural costs that would attend the judicial performance of such work.

These costs go beyond what have been termed administrative costs or error costs-namely, the costs associated with the amount of time it would take to do the additional work or the possibility that erroneous judgments would be made if the work were undertaken. ${ }^{31}$ The costs are of a more normative kind-costs associated with the harm that might be done to the constitutional structure, and the quality of democratic participation under it, if a court attempted to resolve matters that might otherwise be left to the political branches to resolve. One such cost might be that the political branches would be less likely to perceive their own obligations to share in the implementation of the Constitution if the Court attempted to resolve more through its doctrine. ${ }^{32}$ Another might be that more comprehensive judicial intervention would give a false impression as to the nature of constitutional meaning. It would suggest that there is a single right answer to be divined, rather than merely a meaning to be given practical effect through the actions of one or another of the branches of government. A third cost would be that the remedial limitations of a court might artificially limit the range of responses that could be taken to respond to constitutional concerns. ${ }^{33}$

The structural costs of an expanded judicial role are familiarly employed in justifying a deferential judicial stance in the face of a private challenge to a statute's constitutionality. They merit attention here for a different reason. They suggest that a President would be mistaken to read the doctrine as simply a plea to provide the Court with more information in order to ensure that its constitutional judgment will be "more" informed and therefore that its resolution will be "more" accurate. The doctrine may be better read as an invitation for the political branches to act on their own determinations regarding the unconstitutionality of certain governmental action. ${ }^{34}$

31. See Strauss, supra note 18 , at 205.

32. See Cass R. Sunstein, One Case at a Time: Judicial Minimalism on the Supreme COURT 27-28 (1999); SANFORD LEVINSON, CONSTITUTIONAL FAITH 4, 259-60 (1988).

33. See Frank I. Michelman, Property, Utility, and Fairness: Comments on the Ethical Foundations of “Just Compensation" Law, 80 HARV. L. REV. 1165, 1247-58 (1967) (making this point in connection with the scope of the Takings Clause).

34. The classic statement of this position may be found in Thayer's article elucidating the distinction between a legislator and a judge in interpreting the Constitution.

$[\mathrm{O}]$ ne who is a member of a legislature may vote against a measure as being, in his judgment, unconstitutional; and, being subsequently placed on the bench, when this measure, having been passed by the legislature in spite of 
If the preceding account of the doctrine is persuasive, then it should begin to undermine the argument that the President should exercise his nonenforcement authority sparingly, and generally only if doing so would not deprive the Court of jurisdiction. Presidential enforcement of the statute often would, it is true, permit the ensuing constitutional dispute to reach the courts. By contrast, presidential non-enforcement often would not. Even if the President enforces the statute, however, the question would then arise as to what the Court would do with a dispute over the statute's constitutionality once it came before it. That question is unfortunately one that the Court-centered approach to non-enforcement encourages us to overlook.

Attention to that question reveals that the Court might still decline to wrestle with the particular judgment that occasioned the President's constitutional conviction. In such circumstances, it is not clear what would be gained for constitutionalism by ensuring, through presidential enforcement, that the Court have the opportunity to have the final say on the substantive constitutional question. The final say is likely simply to be the product of the application of a doctrinal rule that is designed to permit the political branches to adjudge a certain course of action constitutional in the face of a private party's challenge in court. The Court's doctrine is not designed (or need not be understood to be designed), in other words, to serve as a substitute for a political judgment that such a course of conduct would be unconstitutional.

Of course, even if constitutional doctrine suggests that the Court would resolve the substantive constitutional question only through the application of an institutionally determined rule of deference or prophylaxis, there remain two distinct questions for the President to consider. These are identified above as questions 2 and 3. Before deciding not to enforce a statute on constitutional grounds, the President must still make a judgment concerning the appropriateness of substituting his constitutional judgment for that of the Congress (question 2). In addition, the President must consider whether the determination as to the appropriateness of such substitution is one that the Supreme Court should be given an opportunity to make (question 3). The President's assertion of interpretive authority to decline to enforce a statute would, after all, preclude Congress from implementing its own constitutional vision, and perhaps Congress is entitled to be heard in court on just that issue.

III

\section{DEFERENTIAL DOCTRINE IN ACTION: THREE CASES}

Before proceeding further, it is useful to return to the three possible nonenforcement cases that opened this article: a decision to decline to fire HIVpositive military personnel in the face of a statute mandating their dismissal; a

his opposition, comes before him judicially, may there find it his duty, although he has in no degree changed his opinion, to declare it constitutional.

Thayer, supra note 18, at 144. 
decision to decline to use specified unwarned statements in a criminal prosecution notwithstanding a statute expressly deeming them to be admissible; and a decision to decline to enforce a statute requiring the adoption of differential business regulations that is thought to be the product of nothing more than special interest bargaining. The three cases make it possible to consider more concretely the first question a President should ask before deciding whether to decline to enforce a statute. Even assuming a justiciable controversy brought by a private party, what is the likelihood that the Court would review the particular judgment that has led to the President's conclusion that the statute is unconstitutional? Considering that question in connection with the three cases shows why it would be a mistake to think that the best constitutional answer will result from the Court evaluating the competing substantive constitutional views of the political branches.

The example that begins Professor Johnsen's contribution to this symposium nicely makes the point. The National Defense Authorization Act for Fiscal Year 1996 contained a provision, Section 567, that required the armed forces to fire all HIV-positive personnel. ${ }^{35}$ Appearing as it did as a sole provision in a major authorization bill, the President decided that he could not, as a practical matter, exercise his veto power solely in order to preclude enactment of Section 567. Instead, while signing the bill into law, he declared that Section 567 was "mean-spirited" and unconstitutionally discriminatory under the Due Process Clause of the Fifth Amendment. ${ }^{36}$

The President explained his constitutional conclusion as follows. He stated that he had been informed by his lawyers that the discrimination effected by the statute would be constitutional only if it served "a legitimate governmental purpose." ${ }^{37}$ He explained further that he had consulted with the Secretary of Defense and the Joint Chiefs of Staff, and that he had concluded that "the provision does not serve any valid military or other purpose," and thus that it was unconstitutional. $^{38}$ As a consequence of this substantive judgment, the President announced that he would seek the quick repeal of the provision, that he would provide as many benefits as the law would allow to those persons who would have to be fired by operation of Section 567, and that the executive branch would not defend the statute in a constitutional challenge to the law brought by a fired armed forces employee. Significantly, however, the President concluded that he would enforce the measure because to do otherwise would be to render the case non-justiciable, and thereby to substitute his own constitutional judgment for that of Congress and the Court. ${ }^{39}$

35. See Pub. L. No. 104-106, 110 Stat. 86.

36. White House Press Briefing, 1996 WL 54453, at*1 (Feb. 9, 1996) (statement of Jack Quinn, Counsel to the President).

37. Id. at *2 (statement of Walter Dellinger, Assistant Attorney General, Office of Legal Counsel).

38. $I d$. at $* 2-3$.

39. Id. 
The President appears to have reached his substantive constitutional judgment after having determined that the Court would have applied a rational basis test in reviewing any court challenge to the constitutionality of the discrimination mandated by the provision..$^{40}$ Under that test, as has been suggested, the Court does not attempt to determine for itself that the statutory compelled discrimination is objectively legitimate given all possible evidence regarding the merits of the underlying policy. Instead,

[i]n areas of social and economic policy, a statutory classification that neither proceeds along suspect lines nor infringes fundamental constitutional rights must be upheld against equal protection challenge if there is any reasonably conceivable state of facts that could provide a rational basis for the classification .... [A] legislative choice is not subject to courtroom fact-finding and may be based on rational speculation unsupported by evidence or empirical data. ${ }^{41}$

Significantly, the Court adopts this deferential posture not because of its objective inability to evaluate competing empirical judgments. Courts make such evaluations all the time. The Court instead premises this deferential stance on a structural assertion about its constitutional place relative to the other two branches. As the Court has explained, "[t]he Constitution presumes that, absent some reason to infer antipathy, even improvident decisions will eventually be rectified by the democratic process and that judicial intervention is generally unwarranted no matter how unwisely we may think a political branch has acted." ${ }^{22}$

Taking this doctrine seriously, the President recognized (or asserted) that the Court does not purport, in applying rational basis review, to determine whether a non-suspect legislative classification is legitimate in some comprehensive, final sense. ${ }^{43}$ The Court leaves the ultimate judgment of legitimacy, and, in this respect, of constitutionality, to the political branches. As the head of one of those branches, the President concluded that he had an obligation to make a judgment as to whether such a statute was legitimate. In doing so, he concluded that the statute was unconstitutional without applying the screen of deference that limits the judicial inquiry, but need not, and, indeed, it would appear, in the Court's own view, should not, limit the inquiry of political actors. $^{44}$

It must be emphasized that the President's substantive constitutional judgment in this instance most likely was not the result of a prediction about how the Court would rule if the case were put before it. Professor Powell has quite

\footnotetext{
40. See id. (starting grounds for concluding statute to be unconstitutional that reflect application of the rational basis test).

41. FCC v. Beach Communications Inc., 508 U.S. 307, 313-15 (1993).

42. Id. at 314 .

43. See id. at 315 .

44. There remains the question, of course, of whether the President or Congress ultimately possesses this power of constitutional judgment. At this point, however, the important point is that the Court does not make the ultimate determination of legitimacy, regardless of whether it is the President or Congress that is assigned the final constitutional authority to determine the provision's legitimacy.
} 
plausibly concluded that the Court would have been likely to have upheld Section 567 in the face of a private challenge to it. As he explains,

[j] udged by this standard the argument that a court would have invalidated Section 567 is weak. While the simple fact of being HIV-positive does not render an individual incapable of performing his military duties, it would be difficult to claim that it would be irrational for Congress to conclude that treating HIV-positive individuals for combat injuries would require safeguards otherwise unnecessary, and that as a consequence their presence in combat units would complicate health care under combat conditions. Nondeployability into combat units is an established basis for military classification, and it seems doubtful that a court would conclude that there was no "reasonably conceivable state of facts" justifying Section 567's discrimination. The existence of substantial arguments against the value of the discharge requirement would be irrelevant under the judiciary's version of the rational-basis test. The courts would probably be equally unmoved by the fact that the provision's congressional proponent made remarks that could be construed as showing a bias against HIVpositive persons. ${ }^{45}$

Assuming Professor Powell's predictive account is right, it is difficult to see why the President should understand himself to be required to enforce Section 567. As Professor Powell indicates, substantial arguments questioning the legitimacy of the legislative choice are likely to be quite irrelevant to the Court with respect to any judgment that it would consider itself privileged to make in a constitutional challenge to Section 567. Taking the doctrine seriously suggests that the Court would be quite likely to uphold the statute even if seemingly strong evidence of the absence of any military gain were to be presented. Since a "[l] egislative choice is not subject to courtroom factfinding," and since the democratic processes are presumed to be responsible for rectifying many seemingly unwise political acts, there are structural reasons for having that be the case when rational basis review applies. ${ }^{46}$ What, then, is the value of presenting to the Court the view of the Secretary of Defense or the Joint Chiefs? What is the Court supposed to do with their views, so long as in the absence of them there would be every reason to conclude that the statute would be upheld? Would there not be a structural cost to having the Court independently evaluate such views?

It might be said in response that the usual rules of deference should not apply when the political branches are divided over the substantive constitutional validity of a statute. Perhaps this assumption underlies the court-centered approach to non-enforcement. How, we might ask, could the Court not take into account the statements of the Secretary of Defense or the Joint Chiefs in evaluating Section 567? It might be argued, on this view, that the proper course would be for the Court to attempt to determine the substantiality of the views of the President's military advisers and to weigh them against whatever competing policy claims Congress might present. The Court would then be in the posture of performing a kind of hard-look review of the military judgments of the political branches.

45. Powell, supra note 17, at 382-83.

46. Beach Communications, 508 U.S. at 307. 
Simply to state that possibility, however, is to reveal how substantial a departure from doctrine would be required for this approach to the nonenforcement question to prevail. The Court is disinclined to review legislative judgments concerning social policy generally with rigor approximating hardlook review. It is particularly reluctant to do so when the social judgments at issue concern the needs of the military. Thus, even if it were technically possible for the Court to undertake such review, there would still be the question as to the President's authority to urge the Court to depart from its structurally based, traditionally deferential stance.

The President would be in effect calling upon the Court to give greater scrutiny to a legislative judgment than it would ordinarily provide. What would be his warrant for doing so? We are positing that the President is confident, after all, as Professor Powell has suggested he should have been, that Section 567 would be upheld under rational basis review notwithstanding the substantial evidence that a private party could have put forth against it. It is not clear, therefore, why the President should ask the Court to give less deference to Congress simply because he now has evidence to put forth against it. Any such assertion would have to rest on a claim concerning the relative institutional positions of the President and the Congress with respect to the authority of each to determine whether a particular course of governmental conduct is or is not constitutional. The essence of the dispute concerns structural interpretive authority, rather than the relative correctness of the substantive constitutional judgments that divide the two branches. It seems odd to require such a dispute over structure to be resolved through a judicial inquiry into the objective merits of the substantive conclusions of each branch. Given the Court's own doctrine, the Court would hardly seem to be positioned to render such a decision. And given the political branches' general interest in preserving judicial deference to their substantive judgments, neither the President nor Congress would seem to be positioned to call upon the Court to do so.

There is a potential complication here. The President, in announcing his judgment that Section 567 was unconstitutional, also concluded that it was "mean-spirited." ${ }^{47}$ This statement may suggest that the President believed the statute was motivated by "a bare congressional desire to harm" the class being discriminated against. ${ }^{48}$ Such biased targeting, even of non-suspect classes, sometimes triggers more stringent judicial review in the form of what has been termed "rational basis with teeth." ${ }^{49}$ To the extent that the President based his constitutional judgment on a conclusion of this sort, and to the extent that he thought that the Court itself would have responded similarly to the statute,

47. White House Press Briefing, supra note 36 , at $* 1$.

48. Department of Agriculture v. Moreno, 413 U.S. 528, 534 (1973).

49. Daniel Farber \& Suzanna Sherry, The Pariah Principle, 13 CONST. COMMENT. 257, 260 (196) (citing David O. Stewart, Supreme Court Report: A Growing Equal Protection Clause?, 71 A.B.A.J. 108, $112(1985))$. 
there would be an argument that the submission of competing evidence to the Court would be perfectly appropriate.

The increased scrutiny that the Court performs in such cases, however, is not intended to determine conclusively that a statute is or is not "meanspirited." It simply looks more closely at the connection between legislative means and ends than it normally would. Where the connection seems to be loose, the Court may conclude that the statute is so unlikely to have been motivated by anything other than a bare desire to harm, which would not be a legitimate end of legislation, that the statute must be invalidated. In cases where the Court perceives a tighter connection between means and ends, by contrast, it will not be able to conclude that a private party is entitled to have the Court hold that the statute was motivated by such a venal purpose. This latter judgment of constitutionality, however, is itself made through a screen of deference. It should not be taken to be a conclusive determination that in some objective sense the statute is not impermissibly motivated and thus that it is objectively constitutional.

Unlike the Court, the President need not necessarily assess the wrongfulness of the legislative motive through such a deferential screen. Accordingly, it would not appear that the President's substantive constitutional judgment regarding the lawfulness of the legislative motive would actually be reviewed even if he were to enforce the statute and thereby give rise to a justiciable case. At most the President would be informed that the Court, in light of its own institutional limitations, could not exclude possibly non-venal motivations. Given this, it would not be clear even on the "bare desire to harm" account why justiciability should be the critical factor guiding the President's non-enforcement decision. Justiciability should serve as a constraint, then, only if the President is convinced that he should be bound in evaluating legislative motive by the same screen of deference that the Court would apply.

There may be reasons for concluding that the President should be no more confident of his capacity to evaluate legislative motive than is the Court. There is no need to attempt to resolve that question in the abstract here. It is sufficient to point out that even if the President would not be better positioned to determine actual motive, whatever that might be, he might well be better positioned to make a more calibrated assessment of the legislatively asserted connection between means and ends. In that sense, he may be better positioned to make a more calibrated assessment of the legislative motive than would a court. In other words, in some contexts, the President may be better positioned than a court to conclude that a statute is motivated by what constitutional doctrine calls "animus," if only because his knowledge, experience, and institutional vantage point all suggest that he need not assess the plausibility of an assertedly non-venal legislative motive through the same screen of deference as a judge. That assessment, of course, though formally deemed to be one concerning legislative motive, is hardly different in kind than the judgment about the legiti- 
macy of the claimed need for the legislation that underlay the President's opposition to Section 567.

These questions concerning institutional position must be asked. They make it possible to judge intelligently whether, in order to preserve the possibility of judicial review of the substantive constitutional question, the President should be required to enforce a statute that he believes to be unconstitutional. If there is an interest in having judicial review, it will most likely be because, in the end, the President does not believe that his interpretive authority to resolve the constitutional question concerning legislative motive should be privileged over that of Congress. If that is the case, though, it would seem that the President should be obliged to defend Congress against private challenge, rather than to call its motives into question before the Court. If that is not the case, then, at most, a requirement of enforcement would make sense only in order to permit the Court to resolve the second-order, structural question concerning the relative interpretive authority of the President and Congress. There would be no reason to require enforcement solely so that the Court, institutionally situated as it is, could pass on the substantive question as to whether it believes that the statute is unconstitutional.

To take another example, consider 18 U.S.C $\S 3501$ (1999)..$^{50}$ The statute provides that, notwithstanding Miranda's seeming requirement that certain statements to the police must be excluded from evidence unless they were made after the police provided certain warnings, unwarned confessions are admissible in federal prosecutions. As it happens, this statute was passed soon after Miranda had been decided, which may have made it implausible to conclude that it was anything other than plainly unconstitutional upon enactment. ${ }^{51}$ Moreover, the statute has now been held unconstitutional by virtue of the Court's decision in June in Dickerson v. United States. ${ }^{52}$ Suppose, however, that the statute had been passed a few years prior to Dickerson. Suppose further that its legislative history contained statements in support of Congress's judgment that the provision of warnings was now so much a fixture of federal law enforcement practice, the levels of federal law enforcement training were so high, and the costs of exclusion of evidence so comparatively great, that there was no longer any justification in federal prosecutions for an exclusionary rule to obtain against unwarned statements by the accused.

Prior to Dickerson, it was controversial whether such a statute thus supported would have been plainly unconstitutional under Miranda. ${ }^{53}$ For present purposes, however, assume that the President fairly determined that Congress had a legitimate claim that the statute complied with Miranda or, at least, that,

50. See Pub. L. 90-351, Title II, § 701(a) (1968).

51. In fact, 18 U.S.C. $\S 3501$ was passed in 1968 as a direct response to Miranda.

52. 120 S. Ct. 2326 (2000).

53. The question is controversial not only because of the dispute over whether subsequent precedents have implicitly overruled Miranda, but also because of the possibility that a congressional judgment that circumstances had changed might suffice to undermine the empirical predicate on which Miranda partially rests. 
consistent with the doctrine of stare decisis, Miranda should be overruled because of changed circumstances. Accordingly, the President would not be bound by Supreme Court doctrine to deem the use of the statements unconstitutional; at the very least, he could make a reasonable argument for the decision to be overruled or distinguished in light of new factual circumstances. Moreover, suppose the President was convinced that in light of the current composition of the Court, the direction of recent precedent, and the surprisingly deferential tone toward the federal government that pervades the opinion in Miranda, the Court would be likely to uphold such a federal statute. Would the President nonetheless have the authority to declare the use of the statements unconstitutional and decline to offer any unwarned statements into evidence on constitutional grounds?

As a technical matter, one might conclude that the statute implicitly reserves this discretionary judgment to the President, as he is presumed for constitutional reasons to retain general prosecutorial discretion unless a statute clearly withdraws it. If that is true, then perhaps the President can "frustrate" the statute simply through an exercise of the very residual discretion that the statute implicitly permits the President to exercise. But if the statute could not be so construed, may he nevertheless contravene the statute on the basis of his substantive constitutional judgment? $?^{54}$

The court-centered approach to the non-enforcement question would suggest that he may not. Perhaps not surprisingly, the Administration's position with respect to Section 3501 appears to have been that the provision was unconstitutional but that the Administration would use the unwarned statements if, in a case determining the continuing validity of Miranda, the Court concluded that it could. $^{55}$ The Administration's stance was consistent with the court-centered approach to questions of non-enforcement. Insofar as the President's actions are predicated on a controversial constitutional conviction, and one with which the Court might disagree, the President should use the unwarned statements so as to ensure that the Court may resolve that constitutional dispute. The Court's resolution, whether upholding or invalidating the statute, would then be binding. A contrary approach by the President, the court-centered approach suggests, inappropriately disregards the Supreme Court's special place in the constitutional structure as the final arbiter of constitutional meaning.

54. Even if the statute may be read to prohibit the President from declining to use the evidence unless his determination not to do so rests on a constitutional judgment, it is not at all clear that the court-centered approach would favor such an interpretation of the statutory language. Such an interpretation would privilege the constitutional judgment of the President over that of the Court by permitting the President to moot a justiciable constitutional question through the exercise of a discretionary power to withhold evidence the admission of which he believes to be unconstitutional. It would seem that, under the court-centered approach's conception of the Supreme Court's special role in the constitutional structure, such a construction of an ambiguous statutory text should be disfavored.

55. See Brief for The United States, Dickerson v. United States, No. 99-5525, 2000 WL 141075, at *6 n. 4 (Jan. 28, 2000). 
There is another approach, however, that becomes available if one focuses on the kind of review that the Court could employ in a justiciable case challenging the statutory authorization of the use of the kind of unwarned statements that were at issue in Miranda. A President might notice immediately upon reviewing Miranda that the warnings it prescribed as necessary (though not necessarily exclusively necessary) were taken from the warnings that the Federal Bureau of Investigation had instructed its officers to provide. ${ }^{56}$ The President might notice as well that in the only case before the Court in Miranda involving questioning by federal law enforcement officers, the Court did not appear to require proof that the warnings had been given by the federal officers. $^{57}$ The Court rested its judgment excluding statements in that case in large part on the fact that the suspect had been questioned at length by local officials prior to being questioned by federal authorities; it was the taint that flowed from the local questioning on which the Court rested its judgment. ${ }^{58}$ In addition, the President might notice that the Court's own empirical judgment as to the likely costs of imposing a warning requirement was heavily influenced by its observation that the Federal Bureau of Investigation did not believe that the costs of such warnings were too high. ${ }^{59}$ Finally, the President might notice that the federal government itself had requested in Miranda that the Court withhold crafting a broad rule applicable in all jurisdictions until regulations could be formulated at the state and local level that would presumably mirror the more protective practices of federal law enforcement. ${ }^{60}$

None of this evidence from the opinion would necessarily suffice to suggest to a conscientious President that Miranda was not intended to apply to the federal government. It could be read to suggest, however, that the Court was sensitive, even in applying the exclusionary rule to the federal government, to the superior expertise in matters of law enforcement of federal law enforcement authorities. Respect for that superior knowledge led the Court to adopt its rule in Miranda in a fashion that consciously drew upon the federal law enforcement community's own past practices and judgments about the costs of those practices-practices that were notably more restrictive of police power than those of the states. It would not be at all strange to conclude, therefore, that a current judgment by federal law enforcement as to the necessity and workability of an exclusionary rule would itself be entitled to substantial constitutional weight. In other words, the Executive could conclude that federal law enforcement practices and views at the time of Miranda helped set the possible bounds of the constitutional limitation on governmental conduct that the Court fashioned in Miranda. Similarly, the executive could conclude that current federal law enforcement practices and views regarding the costs and benefits of an exclusion-

56. See Miranda v. Arizona, 384 U.S. 436, $483-88$ (1966).

57. See id. at 494-98. Miranda represented a judgment in several consolidated cases.

58. See id.

59. See id. at 494-98.

60. See id. at 490 . 
ary rule might suggest the need for retaining it now, notwithstanding a contrary judgment by Congress or the Court in deference to the statute.

Interestingly, the Administration's brief in Dickerson, asking the Supreme Court to reaffirm Miranda and to reverse the lower court decision permitting unwarned statements to be admitted pursuant to Section 3501, set forth an argument that is not altogether distinct from the one sketched out above. The Administration's brief argued that while there are costs to an exclusionary rule, there are also important benefits. ${ }^{61}$ In particular, the Administration's brief argued that the Miranda rule has the virtue of providing clear guidance to law enforcement officers, thereby disciplining their police practices and increasing the likelihood that law enforcement officers will provide warnings to suspects in custody, a practice that the brief noted has long been favored by the federal government. ${ }^{6}$ The brief noted further that Miranda has been beneficial because it "facilitates the admission in evidence of confessions that follow the administration of the warnings; it bolsters the credibility of such confessions in the eyes of jurors; and it generally contributes to the perceived fairness of the criminal justice system." ${ }^{63}$ Indeed, the brief contended that "Miranda has come to play a unique and important role in the nation's conception of our criminal justice system: it promotes public confidence that the criminal justice system is fair. Overruling Miranda ... would thus tend to undermine public confidence in the fairness of the system. ${ }^{\circ 64}$

The Administration brief suggested, however, that the question whether Miranda announced a constitutional rule could be determined merely from a consideration of precedents. It suggested that the more empirical determinations concerning the costs or benefits of such a constitutional rule are relevant only to the question of whether stare decisis principles justify affirmance of the prior precedent or its overruling. ${ }^{65}$ To be sure, there was a formal legal question to be resolved in Dickerson concerning whether the Court in its subsequent precedents had effectively held that Miranda did not announce a constitutional rule. There remained, however, a question concerning the substantive premises of Miranda itself. Even if one were to conclude that those subsequent precedents had not deprived Miranda of constitutional force, there remained the question as to the constitutional basis for the Miranda decision itself. As to this question, the Administration's brief seemed to take a purely formal view, as if the Miranda holding rested on nothing other than a construction of text, history and prior precedent. That formal view of Miranda may emanate from the same conception of constitutionalism that underlies the court-centered approach to non-enforcement. Such an approach tends to conceive of constitutional mean-

61. See Brief for the United States, supra note 55 , at $* 9$.

62. Id. at *33-38.

63. Id. at $* 50$.

64. Id. at *49.

65. Compare id. at *11-29 (discussing whether Miranda announces a constitutional rule) and id. at *29-50 (discussing stare decisis). 
ing as something that can be divined by the Court alone using purely formal tools, as if its doctrine is necessarily constructed on the basis of the kind of judgments that by their nature are the province of judges rather than political actors. $^{66}$

If a President were to depart from this conception of constitutionalism, he might conclude that Miranda's substantive constitutional conclusion was predicated in large part on less formal considerations. He might be convinced that its ruling emanated in part from the institutional practices and judgments of federal law enforcement authorities. He might conclude that such an emanation in turn resulted in the imposition of a limitation on the federal government, the bounds of which were partially defined by the practices of the federal law enforcement officials themselves. The President might be inclined to conclude, therefore, that a court judgment upholding the hypothetical version of 18 U.S.C. $§ 3501$ would not reflect a determination that the Constitution, as an objective matter, fails to require an exclusionary rule for unwarned statements. He might be convinced that such a judgment would be the product, in significant part, of a deferential assessment of the more functional judgments of the federal government regarding the costs and benefits of an exclusionary rule. As a result, the President might conclude that, even if the Court would not strike down a statute that would permit (or require) the admission of unwarned statements into evidence, the Constitution nonetheless bars the executive branch from admitting such evidence, the statute notwithstanding. This presidential judgment as to constitutional meaning would rest on an assessment of the factual predicate for a constitutional rule barring the admission of unwarned statements. That predicate would be the same one that Congress had assessed, albeit in a controversial manner, in enacting the hypothesized Section 3501. Whatever his disagreement with Congress's assessment, the President might be confident that each of the political branches was better positioned to undertake such functional assessment than the courts.

The Court might, of course, reject the statutorily enunciated judgment that an exclusionary rule is unnecessary, unworkable, or too costly. To the extent that the Court were to credit that statutory judgment on grounds of deference, the resultant constitutional judgment that the Court would announce could not be divorced from the institutional structure that produces it. The Court would at most be adjudicating the relative authority to resolve substantive constitutional meaning in a dispute between an accused defendant and the political branches of the United States (albeit in a circumstance in which the political branches were themselves divided).

Consequently, the President might conclude that in a case challenging the statute, the Court's actual judgment would be made through a screen of deference. To that extent, therefore, the President may fairly wonder why it is critical that his judgment as to the constitutional necessity of an exclusionary rule be

66. It must be admitted that the Court's ultimate decision in Dickerson adopted a similarly formal approach. 
reviewed by the Court. It may be that there would be utility in having the Court essentially validate his own substantive constitutional judgment over the contrary judgment of Congress. But what if the President were convinced that the Court would not do so because of the limitations that the demands of deference appropriately place on its decisional authority? What basis would there be for a conclusion that the Court would be in a position to evaluate the type of dispute over the need for an exclusionary rule that divides the President and Congress? Why should the President not conclude that, taking the relevant doctrine seriously, he is in a better position than the Court, though perhaps not Congress, to evaluate the likely consequences that would flow from permitting unwarned statements to be used in evidence? Surely as the chief federal law enforcement officer, the President would seem to be positioned to undertake such an inquiry.

Moreover, the President may conclude that it is most unwise to invite the Court to depart from the essentially deferential stance to federal law enforcement that the Court adopted in Miranda. He may not wish to suggest that a private party challenging 18 U.S.C. $\$ 3501$ should be permitted to undermine a statutory conclusion through courtroom factfinding even when, as here, such an undermining of statutory judgments would redound to vindicate his own constitutional judgment. Nor may he wish to suggest that the exclusionary rule for unwarned statements involves only a question of formal meaning, divorced from more empirical judgments of costs and benefits. After all, such a suggestion seems to make binding a judicial decision to affirm the statute despite the President's constitutional conviction to the contrary. The President's dispute with the constitutional judgment of Congress, in other words, may be one that is solely with Congress. It is a dispute that occurs in the shadow of the Court's doctrine, and the President may be that convinced that it should remain there.

Finally, the President may realize that by inviting the Court to weigh his assessment of consequences against Congress's, the President would necessarily be arguing that he is entitled to subject the statute to a more severe form of judicial review than would ordinarily obtain. The President's warrant for doing so, however, would have to rest on a claim about the relative authority of each of the political branches to implement the Constitution. If that is the essence of the dispute, it seems odd to call upon the Court to mediate it through a substantive evaluation of each branch's assessment. After all, the President is convinced that each branch's evaluation, predicated as each would be on a practical determination, is superior in a structural sense to the one that the Court could offer. Why then have the Court substitute its substantive judgment for their competing substantive judgments? At most the Court would appear to have a role to play in resolving the structural dispute over the relative interpretive authority of the competing political branches. Its authority to resolve that structural dispute, however, does not imply an authority to resolve the underlying dispute over the substantive constitutional question that divides the political branches. 
It should now be apparent that this same type of analysis could apply as well to the third case set forth at the outset of this article. That case concerns a President's decision to decline to enforce a statute requiring the Administration to apply differential business regulations to seemingly similar professions out of a concern that the differential regulatory burden is the product of an illegitimate, and thus unconstitutional, legislative distinction. To be sure, if the President decided to carry out the statute's purpose, the Court would be likely to uphold the resulting regulations against a constitutional challenge that they violate a constitutional norm of equality. At the very least, the President would surely be acting reasonably in defending such regulations (and the underlying statute requiring their promulgation) against such private challenge. The rational basis test would clearly be applicable to legislation of this type. The statute establishes a classification in a commercial context that does not affect a suspect class or tread upon a fundamental right. It would be unlikely, therefore, that the Court would strike down the statute merely because it was the product of special interest bargaining.

It is unlikely but not inconceivable. There are precedents enough to suggest that the test of legitimacy under the rational basis standard of review can be flunked on grounds other than animus. A court would be loath to judge a distinction arbitrary even if it seemed to be explicable only as a consequence of special-interest deal-making. The doctrine nevertheless suggests that such pure deal-making or favoritism of a private interest for no public purpose is illegitimate. ${ }^{67}$ That doctrinal suggestion would therefore provide a space that would allow the President to understand himself to be vindicating a constitutional limitation in declining to promulgate the differential business regulations notwithstanding the statute's mandate. That space would exist even though the doctrine would not lead the Court, positioned as it is, to the same judgment, if it were called upon to review the statute or the resulting regulations.

Moreover, as in the other two examples, the doctrinal space that would permit the President to reach such a conclusion would also suggest that there would be little reason to ensure that such a conviction would be reviewed by the Court. The very deference on which the doctrine rests makes it difficult to see what would be gained by returning to the Court for a review of the constitutional judgment that the President had reached. What divides the President and Congress is a conclusion as to the degree to which some public, non-dealmaking purpose justifies the legislation. The doctrine is designed, however, to ensure that the Court does not have to adjudicate such questions in cases challenging the rationality of statutes that are brought by private parties. Why, then, have the Court intervene to resolve the substantive dispute between the branches?

The discussion thus far does not resolve the question in favor of the President exercising the non-enforcement power in any of the cases addressed

67. See Cass R. Sunstein, Public Values, Private Interests, and the Equal Protection Clause, 1982 SUP. CT. REV. 127, 165 (discussing this point in connection with rational basis review). 
above, let alone whenever the President believes a statute to be unconstitutional. It demonstrates only that a determination that a statute is unconstitutional often will be the product of a form of reasoning that doctrine suggests (or should be understood to suggest) the Court will not itself perform in a justiciable case. This basic limitation on the Court's decisional processes cannot be overcome, therefore, simply by supplying the Court with more information. It can be overcome at most only with arguments as to why the Court's decisional processes should not be so limited in cases where the President and Congress are divided on a substantive constitutional question.

Those arguments, it has been suggested, necessarily turn on contentions about the relative authority of the two branches to decide constitutional questions and the authority of the President to make the Congress meet a higher standard of proof than it would ordinarily be called upon to bear in a constitutional case before the Court. ${ }^{68}$ It has been suggested as well that there are structural costs to such arguments succeeding. Such arguments assume that constitutional meaning is ultimately something that the Court alone is capable of discerning. If successful, such arguments would expand the scope of the Court's decisional power in a manner that ultimately neither the President nor Congress may favor. At the same time, such arguments impliedly assume that the Court possesses a preclusive power to resolve constitutional meaning. As a result, these arguments implicitly confine the possible scope of substantive constitutional limitations to those that a particular institution, the Court, is prepared to acknowledge.

There may still be reasons to confine the President's exercise of the nonenforcement power with a justiciability constraint. There are reasons to be wary of predicating such a constraint on the need to ensure that the Court will have an opportunity to pass on the substantive constitutional dispute that divides the political branches. Nonetheless, there might be reasons to conclude that such a constraint is necessary to ensure that a court has an opportunity to adjudicate the structural dispute that divides the President and Congress: namely, the dispute over the relative authority of each to resolve substantive constitutional questions. To examine the merits of that contention, it is important first to determine what entitles the President to contend that the Executive branch's constitutional views should prevail over those of Congress.

IV

\section{THE RELATIVE INTERPRETIVE AUTHORITy OF THE POLITICAL BRANCHES}

It could be argued that the President's role in the lawmaking process is clearly confined in the Constitution to either signing a bill into law or exercising the veto power. The President may make his constitutional views determinative of whether a law shall have effect at the moment at which the President decides either to sign or to veto legislation. In circumstances where the President has

68. See supra at pages 91-95. 
chosen not to exercise that veto power, as was the case with respect to Section 567 , or where the veto has been overridden, all that remains for him to do is to enforce the duly enacted law. ${ }^{69}$

The Clinton Administration's non-enforcement opinion is persuasive in contending that the availability of the veto power should not be fatal to a claim of non-enforcement. It is far from clear that a proper respect for congressional power warrants a conclusion that would preclude a subsequent President from giving effect to his own constitutional vision merely because a predecessor declined to employ the veto power. It would be odd as well to conclude that the President has no choice but to enforce a statute that is plainly unconstitutional in the eyes of the Court. There is also the practical reality that, in an era of omnibus legislation, a requirement that the veto power alone be employed would significantly restrict the President's authority to realize his constitutional vision in any case in which a constitutionally troubling measure was attached to pressing, but otherwise constitutionally uncontroversial, legislation. Moreover, the constitutional text certainly cannot be said of its own force to require such a construction, and, as the Clinton Administration opinion demonstrates, longstanding executive practice is inconsistent with any such categorical interpretation. $^{70}$ Taken together, these reasons suggest, as Professor Johnsen well explains, ${ }^{71}$ that some non-enforcement power inheres in either the Take Care Clause or in more implicit structural presuppositions. The critical question concerns less whether any such power exists at all, than what the scope of that power should be. ${ }^{72}$

In resolving the question of scope, the President could believe that, as the head of a coordinate branch of government, he is no less entitled than Congress to come to a conviction about the Constitution's meaning. One could accept that both the President and Congress are bound to respect Supreme Court judgments that certain courses of governmental conduct are unconstitutional. One could nonetheless believe that the chief executive should be just as free as Congress to adjudge conduct unlawful even though the courts would uphold it. Congress, in the performance of its constitutional functions, may act on the basis of its own constitutional vision, thereby declining to adopt certain legislation that the President may have favored. Perhaps, then, the President may in the performance of his constitutional functions act on the basis of his own constitutional vision, thereby declining to enforce legislation that Congress favors.

The argument would draw strength from the text of the Take Care Clause. The Clause confers, or imposes, upon the President the unique constitutional responsibility to ensure that the laws are faithfully executed. The Constitution

69. See Johnsen, supra note 2, at 14-16 (setting forth and criticizing this view).

70. See Presidential Authority to Decline to Execute Unconstitutional Statutes, 18 Op. Off. Legal Counsel 1999 (Nov. 2, 1994).

71. See Johnsen, supra note 2, at 34-36.

72. See David S. Strauss, Presidential Interpretation of the Constitution, 15 CARDOZO L. REV. 113, 117 (1993). 
itself, on this account, is one of the laws that must be faithfully executed. Thus, the President may argue that it is quite clear that he has not only the authority, but the duty to enforce the Constitution, as supreme law, even if that means, as a consequence, declining to enforce a statute that is in conflict with the Constitution. $^{73}$

There is a significant problem with resolving this question of scope in such an absolutist fashion. It is a problem that mirrors the mistaken conception of constitutional meaning outlined above. The Court in enforcing the Constitution does not purport to do so in a vacuum. It attempts only to implement the Constitution in light of its position within a constitutional structure that divides authority between distinct types of governmental institutions. The Court has adopted limitations on the scope if its own interpretive authority out of respect for coordinate branches of government. These limitations suggest that the President should be wary of a view of the Take Care Clause that would discount the competing interpretive capacities of other institutional actors, the Congress included.

A broad assertion of final presidential authority over all constitutional questions, regardless of the competing constitutional vision that Congress may have asserted, seems to be inconsistent with the very notion of a structure of coordinate branches and separated powers. At the very least, it certainly seems that such an expansive view of presidential non-enforcement power should not be an available line of argument if one wants to challenge the court-centered approach on its own terms. Such an expansive conception of presidential authority, after all, would rest on a conception of the constitutional structure that would be blind to the ways in which constitutional doctrine itself suggests that the scope of an institution's interpretive authority is defined by a structure in which there are three branches sharing power rather than one branch exercising all of it.

As we have seen, the Supreme Court, in giving life to the Constitution, is bound by rules of deference to competing interpreters in many contexts. Those rules seem reflective of the Court's role in the constitutional structure rather than antithetical to it. So, too, the President should understand himself to be bound by rules of deference to competing interpreters, the Congress included. That is particularly true in contexts where the constitutional structure suggests that the interpretive judgment to be made is one over which Congress, rather than the President, should have primary decisional authority. The President may, it is true, be in some sense implicated in the constitutional harm that follows the carrying out of an unconstitutional law by virtue of his enforcement of that law. That circumstance, however, should not free him of the demands of deference any more than the Court's implication in that harm by virtue of its entry of a judgment should free it of similar demands. The President's oath to

73. See generally Michael S. Paulsen, The Most Dangerous Branch: Executive Power to Say What the Law Is, 83 GEO. L.J. 217 (1994) (arguing that the President has co-equal interpretive authority with the courts). 
protect, preserve, and defend the Constitution, no less than his obligation to take care that the laws be faithfully executed, comport with a mode of enforcement that is predicated on deference to competing interpreters in certain circumstances. For it is just such deference that the President is committing to provide in taking his oath and assuming his obligation to faithfully execute the laws. The demands of deference that free the President to adjudge laws unconstitutional that the Court would uphold also may serve to constrain the President to enforce laws he believes to be to be unconstitutional but that the Congress has enacted.

Moreover, it is possible to consider the Take Care Clause in less absolutist terms that permit the demands of inter-branch deference to constrain the President's independent interpretive authority. Supreme Court doctrine indicates that the political branches are often better positioned, as a matter of constitutional structure, to make the evaluation of substantive unconstitutionality than the Court itself would be. The same might be true in disputes between the President and Congress. It is only in circumstances in which such a judgment would be persuasive on this account that the non-enforcement power would lie.

Thomas Jefferson's famous statement of the President's interpretive authority to deem actions by the competing branches unlawful provides some support for a structural approach to the exercise of the non-enforcement power that would sanction its exercise in some but not all cases. Writing to Abigail Adams, Jefferson explained:

\begin{abstract}
You seem to think it devolved on the judges to decide on the validity of the sedition law. But nothing in the Constitution has given them a right to decide for the Executive, more than to the Executive to decide for them. Both magistracies are equally independent in the sphere of action assigned to them. The judges, believing the law constitutional, had a right to pass a sentence of fine and imprisonment; because that power was placed in their hands by the Constitution. But the Executive, believing the law to be unconstitutional, was bound to remit the execution of it; because that power has been confided to him by the Constitution. That instrument meant that its coordinate branches would be checks on each other. But the opinion which gives to the judges the right to decide what laws are constitutional, and what not, not only for themselves in their own sphere of action, but for the Legislature \& Executive also, in their spheres, would make the judiciary a despotic branch.
\end{abstract}

Jefferson need not be understood to be arguing broadly that the relevant sphere of action to be compared among the branches is constitutional interpretation as such. Rather, he may be understood to be arguing only that the President has the constitutional authority to exercise the pardon power to remit sentences, and that in the exercise of that constitutionally vested power, he is free to make a judgment as to a law's unconstitutionality. The judiciary's contrary judgment as expressed in performing the quite distinct task of rendering a sentence should not be understood to be preclusive of that authority.

Jefferson's approach is useful not because it proves how the Framers would have approached the question. It almost certainly does not. It is useful because

74. Peter M. Shane \& Harold BrufF, The LAw of Presidential Power 396 (1988) (quoting VIII WRITINGS OF THOMAS JEFFERSON 310 (P. Ford ed. 1897)). 
it offers a persuasive approach in its own right. It takes cognizance of the manner in which the constitutional structure divides power in order to promote a sharing of constitutional interpretive authority through the exercise of the powers that the Constitution grants to the various branches. It is useful as well because Jefferson's approach resonates with the approach that the Court has taken in its own doctrine with respect to the scope of its interpretive authority under the Constitution. The Court has not attempted to assert itself as a final authority on constitutional meaning in all cases that come before it. It has rather attempted, even in the course of asserting its authority to place limitations on other branches of government, to leave room for other branches to make constitutional judgments on their own. In doing so, it has situated itself within the constitutional structure, taking account, as best as it can, of its own institutional advantages and limitations. A similar structural sharing of interpretive authority might therefore be understood to be expected to occur between the political branches.

This approach to the scope of the non-enforcement power suggests that it is critical for the President to assess his place in the constitutional structure in determining the scope of his non-enforcement power. It would not be enough, on this view, for the President to assert that he has adjudged a statute unconstitutional and therefore that he must not give it effect. He must also assess whether the matter at hand is one over which he has interpretive authority relative to the competing branches. As has been suggested, he will often conclude that the constitutional structure suggests that he does possess interpretive authority relative to the Court by virtue of the screen of deference through which the Court creates constitutional doctrine. It will also sometimes suggest, though many times it will not, that he possesses a similar authority with respect to Congress.

The pardon power is obviously an unusual grant of interpretive authority to the President, but it is not necessarily an exclusive one. Here, the general framework for analysis of the scope of power of the competing political branches may prove to be helpful. The basic separation of powers framework for analyzing the scope of presidential authority is set forth in Justice Jackson's famous concurrence in Youngstown Sheet \& Tube v. Sawyer, ${ }^{75}$ which addressed the constitutionality of President Truman's seizure of steel mills. The Jackson concurrence explains that the President's independent authority to act must rest on an exclusive power in order to be exercised in express derogation of a congressional prohibition. In areas in which there is "a zone of twilight in which he and the Congress may have concurrent authority," the President may act without express statutory authority so long as Congress has not forbidden it. ${ }^{76}$ Otherwise, the President may act only when authorized by statute to do so.

Here, we are concerned not with the President acting in the conventional sense of asserting power over individuals or entities, but rather with the President refusing to act in order to protect the statutory targets of enforcement

75. 343 U.S. 579, 634-35 (1952).

76. Id. at 637 (Jackson, J., concurring). 
from the imposition of governmental power. As a consequence, we might conclude that even though every assertion of the non-enforcement power is necessarily in derogation of a congressional command, the President need not be understood to be limited to asserting the non-enforcement power only pursuant to the exclusive powers-such as the Pardon Power-that the Constitution affords him. We might conclude that the non-enforcement power should exist with respect to those matters within "the zone of twilight" that Justice Jackson identifies. $^{77}$

With the frame thus shifted, it might seem that every case of nonenforcement should be deemed within the zone of twilight. The constitutional text is unclear as to the scope of the non-enforcement power, and the power itself strikes at the heart of the President's role as a coordinate constitutional actor in that he alone is ultimately responsible for actually carrying out the policy that has been enacted into law. ${ }^{78}$ If that were the case, then the zone of twilight metaphor that Justice Jackson employed would have little constraining effect on the scope of the President's interpretive authority. It would simply serve metaphorically to describe the existence of a broad and unilateral presidential power that would be available in all cases. It would make the power seem more exclusive than concurrent. It seems a mistake, however, to conceive of the zone of

77. This analysis parallels that set forth in Professor Strauss's article in this symposium. See Peter Strauss, The President and Choices Not to Enforce, 63 LAW \& CONTEMP. PROBS. 107 (Winter/Spring 2000). It is useful to distinguish in this regard between two types of statutes. Some statutes act directly to affect the rights and obligations of private persons at the moment of their passage, either by declaring certain private activity to be unlawful, as the criminal drug laws do, or by imposing financial liabilities upon non-governmental actors, as provisions of the tax code do. The non-enforcement power may be exercised in only a partial sense with respect to such provisions. The President may refuse to institute prosecutions or collection actions, but such refusals cannot suffice to prevent these statutes from having an operable chilling effect upon the conduct of its targets. The chilling effect persists because it is not obvious that even an executive's express commitment not to enforce will suffice to terminate the risk of future prosecution or collection that may arise from the legislative judgment of criminality or liability. Other statutes, by contrast, affect the rights and obligations of private persons only indirectly through the commands or limitations they impose upon the executive. The non-enforcement power may be exercised in the full sense with respect to such statutes. Indeed, the three hypothetical nonenforcement cases that have been discussed so far involve statutes of this latter type. These statutes purport to affect non-governmental targets indirectly through their commands to the executive: Fire HIV-positive military personnel; admit statements in criminal prosecutions even though they were provided without prior warnings; and promulgate certain regulations but not others. The President may preclude these statutes from having any operable effect simply by refusing to act. Indeed, it is for that reason that the non-enforcement decision in these cases threatens to render a constitutional dispute non-justiciable. Of course, this distinction will not always hold. One can imagine, for example, a statutory direction to the Federal Communications Commission to decline to renew broadcast licenses for broadcasters that fail to air sufficient local programming. An executive branch assertion that such a provision is unconstitutional may not suffice to allay broadcaster concerns that current programming choices will figure in future renewal decisions.

78. For present purposes, and notwithstanding the previous note's reference to the Federal Communications Commission, the analysis focuses solely on statutes that contemplate direct presidential enforcement, or enforcement by actors plainly subordinate to the President. Whether the nonenforcement power should be understood to operate with the same force as against a statute that directs an independent agency raises potentially distinct questions. 
twilight in this fashion. Justice Jackson identified it as the area within which the President possessed concurrent, rather than exclusive power.

A consequence of Justice Jackson's typology, moreover, was that Congress possessed the authority to preclude the President from acting if it made its intention clear enough with respect to those matters within the zone of twilight. If there is a non-enforcement power in the executive, however, it is not one whose contours should be a function of congressional command. Congress could not pass a general statute precluding the exercise of that power across the board and thereby deprive the President of that power. Nor would it seem sensible to presume that it is unclear whether Congress would in fact intend to command the President to enforce a statute despite his constitutional misgivings. ${ }^{79}$ It seems quite sensible to conclude that Congress intends for the statutes it enacts to be enforced notwithstanding a President's constitutional qualms.

If the zone of twilight metaphor is to be helpful, its utility is to be found in its identification of areas in which there is a structural presumption of independent executive authority. In these twilight areas, where the President is free to act in the absence of express or implicit congressional authorization, it is presumed that the constitutional structure affords the President a measure of institutional authority that entitles his judgment to significant weight. These areas would seem to constitute a good proxy for the types of areas in which the President's constitutional judgment should be entitled to weight in a structural sense. In these areas, the President is not the mere minister of congressional will; he is structurally presumed to be an independently responsible constitutional actor. As such, it would seem a sound construction of constitutional structure to permit him to assert his substantive constitutional views only with respect to such matters.

There has been little elucidation, in the years following Justice Jackson's concurrence, as to the contours of the zone of twilight. The classic areas in which there is thought to be concurrent executive and legislative authority concern foreign affairs and national security matters. ${ }^{80}$ Issues concerning the military also are generally thought to fall into this category. Indeed, it is no doubt because of the presumption of concurrent, though not exclusive, presidential authority in these areas that the usual rules governing the specificity of congressional delegation of authority to the President are expressly relaxed as to matters pertaining to the exercise of military, foreign affairs, and national security

79. At the same time, as will be discussed later, Congress is not powerless to protect its interests against non-enforcement. There are, as an initial matter, the usual means, albeit political rather than legal, of legislative oversight of executive branch action. In addition, Congress would still retain the power to confer a cause of action on statutory beneficiaries to bring to a court the claim that, in the context at issue, the President lacks the kind of structural authority to substitute his constitutional judgment for that of Congress that would entitle him to decline to enforce a duly enacted law.

80. See Russell Dean Covey, Note, Adventures in the Zone of Twilight: Separation of Powers and National Economic Security in the Mexican Bailout, 105 YALE L. J. 1311, 1314-24 (1996) (reviewing the doctrine). 
matters. ${ }^{81}$ The Court evinces little concern with sweeping standardless delegations in these areas precisely because of the structural presumption in favor of executive, rather than legislative, decisionmaking over such matters.

That a similar structural presumption in favor of sweeping standardless delegations applies to the executive's exercise of the criminal prosecutorial function suggests that this function also exists within the zone of twilight. To be sure, the President has no authority to prosecute anyone for a criminal offense in the absence of a sufficiently specific statute criminalizing the conduct that gives rise to the prosecution. The manner in which the executive exercises its discretion to prosecute those offenses that have been specified as criminal by statute, however, is a matter over which the President is presumed to possess implicit, sweeping, and relatively unguided discretion. ${ }^{82}$ That presumption of authority explains not only why Congress need not specify enforcement standards in legislation to guide the executive in the carrying out of his prosecutorial functions, but also why the executive branch need not make public in advance the standards that it will employ to carry out that function. Indeed, the Court's recent decisions rejecting constitutionally-based claims of selective prosecution reflect the structural presumption of independent executive authority to define enforcement criteria and methodologies, even though such decisions do not go so far as to demonstrate that such discretion is exclusively vested in the executive branch. ${ }^{83}$ The same presumption of structural authority that justifies the exercise of such unconstrained, delegated discretion suggests that the exercise of prosecutorial discretion is also within the zone of twilight. ${ }^{84}$

With this background in place, it is useful to return to the three nonenforcement cases set forth above, starting first with the example of Section 567. It is quite likely that the President's confidence in declaring the provision unconstitutional owed to his understanding of the authority that he has been granted under the Constitution as commander-in-chief. ${ }^{85}$ Congress has constitutionally vested authority to prescribe regulations for the armed forces, and thus the President could not claim an exclusive interpretive authority, as he might with respect to the pardon power. In light of the President's commander-inchief powers, it nevertheless seems quite reasonable to conclude that as a matter of structure the President possessed an authority not unlike that Jefferson believed he possessed under the Pardon Clause. At least, given Congress's own textual grant of authority to regulate the military, ${ }^{86}$ it seems reasonable to con-

81. See, e.g., United States v. Loving, 517 U.S. 748, 750 (1995) (discussing delegations concerning military matters).

82. See SHANE \& BRUFF, supra note 74, at 396, 438-39 (discussing prosecutorial discretion).

83. See, e.g., United States v. Armstrong, 517 U.S. 456, 464 (1996); United Sates v Whren, 517 U.S. 806, 813 (1996).

84. This list, it should be apparent, is not intended to be exhaustive or exclusive. It is rather suggestive of the types of areas within which the President's structural claim to relative interpretive authority is likely to be greatest.

85. See U.S. CONST. art. II, § 2, cl. 15 .

86. See id. art. I, § 8, cl. 15 . 
clude that the question concerned one over which the political branches share power and thus that the President was not in a position where, as a matter of constitutional structure, he should simply defer to the legislative judgment. In this respect, we might say that the interpretive question arises in the zone of twilight Justice Jackson identified.

A more difficult case is presented by the hypothetical version of 18 U.S.C. $\S$ 3501. There, the President has no express textual grant of authority analogous to the commander-in-chief power. Nevertheless, the President does possess the executive power itself, which, along with the Take Care Clause, has been the basis for the traditional presumption of broad prosecutorial discretion to refrain from bringing charges, even in the face of intense political pressure to do so. ${ }^{87}$ It may be that Congress possesses the constitutional authority to divest the President of that authority, but so long as it continues to grant federal prosecutors broad authority to make lenient charging decisions and to refrain from engaging in harsh practices, the President may well conclude that it cannot now oust him utterly from making a judgment as to constitutionality of excluding unwarned statements alone. ${ }^{88}$ The overall statutory framework of the criminal code everywhere reflects an abiding trust in the executive branch's structural authority to make judgments concerning the manner in which prosecutions are carried out. The decision that certain evidence should not be used in making a case would seem to be central to that generally unrestricted authority to refrain from prosecuting. The imagined Section 3501 would restrict prosecutorial discretion by compelling the admission of evidence that the executive branch believes should not be used.

The structural presumption of independent executive authority to control prosecutorial practice should not fall away for purposes of delimiting the bounds of the non-enforcement power simply because Congress has identified a single practice over which it wishes to assert final authority. After all, Congress would not be engaged in substantive criminal law definition in enacting the Section 3501. Rather, it would be engaged in the regulation of federal prosecuto-

87. See Heckler v Chaney, 470 U.S. 821, 832 (1985).

88. It bears emphasis that the President's asserted authority to disregard a statutory direction concerning the exercise of his prosecutorial discretion would, in the context anticipated here, not flow from a broad-based assertion of executive authority. The President's asserted authority emanates from the conviction he has reached regarding the substantive constitutional limitations that the Fifth Amendment places on the admission of unwarned statements of the type that were at issue in Miranda. His authority to assert that substantive constitutional judgment in the face of a contrary statutory command has weight because the statutory command proposes to direct the exercise of prosecutorial discretion. Thus, it is the conjunction of a substantive constitutional conviction and the exercise of a function-the exercise of prosecutorial discretion - that the constitutional structure presumes to be within the President's control that forms the basis for his authority to disregard a congressional enactment. Neither the substantive constitutional judgment nor the fact that the statute purports to direct the exercise of presumptively unfettered prosecutorial discretion would, standing alone, suffice to justify the exercise of the non-enforcement power that is contemplated here. This distinction is sometimes lost in the course of defenses of the President's prosecutorial discretion. Cf. Brief of Benjamin R. Civiletti, Dickerson v. United States, No. 99-5525, 2000 WL 122082, at *7-16 (Jan. 28, 2000) (blurring this distinction at various points). 
rial practices. Congress has not purported to exercise its Article I powers to declare any particular conduct by private parties unlawful; it has instead acted, in adopting the hypothesized Section 3501, against the President's exercise of enforcement discretion directly. It is precisely with respect to decisions concerning how substantive criminal offenses should be prosecuted, rather than what conduct should be deemed criminal, over which the President is presumed to possess a measure of independent structural authority. A single congressional enactment hardly seems sufficient to support a conclusion that a presidential judgment as to the constitutionality of a prosecutorial practice should be given no weight under our constitutional structure. ${ }^{89}$

These cases are each distinguishable from the third case in which the President would be hard pressed to conclude that he possesses anything akin to the kind of exclusive constitutional interpretive authority Jefferson had identified. Suppose Congress passes legislation that requires the Administration to promulgate more onerous business regulations on optometrists than opticians. The President may be convinced that such differential regulation is the consequence solely of private interest lobbying or corruption and is utterly arbitrary. The President would certainly have authority to institute investigations of such corruption (and even to give priority to such investigations because of his constitutional concerns), or to veto the statute prior to its enactment. On the approach set forth here, it is doubtful, though, that he would be well-situated to argue that he possessed the constitutional authority to decline to enforce the statute on constitutional grounds.

The Supreme Court would probably uphold the statute, and resulting regulations, against private challenge. ${ }^{90}$ More importantly, the President does not possess shared, let alone independent, constitutional authority to make judgments as to the needs for such commercial legislation in the way that he possesses general authority over the military or criminal prosecutorial decisions. His job is the more ministerial one of implementing those commercial policy judgments that Congress has made.

The analysis set forth above also provides a basis for justifying the presidential decisions that have been undertaken to frustrate the implementation of congressional statutes on the ground that they impermissibly infringe executive branch prerogatives. A key justification for the President's longstanding assertion of a broader non-enforcement power with respect to statutes that infringe

89. The line between the definition of a substantive criminal offense, over which Congress may be presumed to have superior structural authority, and the manner in which such substantive offenses should be prosecuted, is not obvious in all instances. As recent literature has pointed out, the line is blurring. See William J Stuntz, Race, Class, and Drugs, 98 ColuM. L. REV. 1795 (1998); William J. Stuntz, The Uneasy Relationship Between Criminal Procedure \& Criminal Justice, 107 YALE L.J. 1 (1997). As a consequence, a President, for example, may contend that the differential substantive regulation of seemingly equivalent drug offenses is actually a regulation of prosecutorial discretion itself. At the limit, however, it remains meaningful to distinguish between a statutory regulation of private conduct and a statutory regulation of an executive's manner of prosecuting such conduct.

90. See supra text accompanying notes 19-20, 40-42 (discussing application of rational basis review to such a statute). 
on executive prerogatives directly, as occurs in classic separation of powers confrontations between the President and Congress, has been that nonenforcement tends to render such disputes justiciable. ${ }^{91}$ It is more likely, however, that the assertions of an expanded non-enforcement power in these contexts arises from the President's own assessment that he is at least as wellpositioned as Congress to adjudge the scope of his constitutionally vested powers. That non-enforcement renders such cases justiciable is simply an incidental consequence.

To the extent the President's structural assessment is sound in these cases, justiciability quite properly is not of foremost concern. Indeed, if one reads presidential signing statements, one finds them replete with what amount to declarations that various incursions on presidential authority, in the form of restrictions on the foreign affairs or appointments powers, will be treated as precatory. ${ }^{92}$ Such assertions are made even though the President is aware that no justiciable dispute is likely to arise from such treatment, and even though, often times, the substantive constitutional claim that underlies such treatment is itself far from settled as a matter of Supreme Court doctrine.

Even if the President concludes that both branches are better positioned than the Court to resolve the substantive constitutional question at issue, and even if the President decides that he should at least possess an interpretive authority over that question that is equivalent to Congress's, the case might still be made for a blanket justiciability constraint on the non-enforcement power. It might be argued that the President's interpretation of the scope of the executive's interpretive authority within the constitutional structure is at bottom a legal one concerning the separation of powers. Thus, one could agree that Congress should be permitted to contest the interpretation in a court of law. Accordingly, it might be contended that even if the dispute that the Court should be called upon to resolve is only the second-order, structural dispute concerning the proper allocation of interpretive authority between the branches, the President should still consider himself bound to ensure that the Court has the opportunity to make that determination.

\section{$\mathrm{V}$}

\section{RESOLVING INTER-BRANCH DISPUTES OVER INTERPRETIVE AUTHORITY}

Having come this far, it is tempting to conclude that justiciability cannot be a constraint on the non-enforcement power because the second-order, structural question of relative interpretive authority is itself a political question over which the Court would not have decisionmaking authority. One could argue that the question meets the criteria of a political question. ${ }^{93}$ The scope of the

91. 18 Op. Off. Leg. Counsel at 201.

92. See, e.g., Federal Election Commission v. NRA Political Victory Fund, 6 F. 3d 821, 824-25

(1993) (citing such signing statements).

93. See Laurence H. Tribe, American Constitutional Law 96-107 (2d ed. 1988). 
authority to decline to enforce a statute that the President believes to be unconstitutional is arguably textually committed by virtue of the Take Care Clause. Resolution of the question would also require the Court to resolve delicate inter-branch disputes.

Whatever superficial appeal such a claim might have, it will not ultimately suffice to resolve the difficulty. It would be a cheat to conclude otherwise. The dispute between Congress and the President over the scope of the nonenforcement power is ultimately of a piece with separation of powers contests generally. It is a dispute over the institutional prerogatives of each branch. It is quite clear that the Court is more than willing to adjudicate such disputes, even when, as Myers $v$. United States ${ }^{94}$ shows, the constitutional claim turns in part on the meaning of the Take Care Clause. ${ }^{95}$

In adjudicating these disputes over institutional power, the Court does not purport to leave it to the executive branch to conclude that a statute is unconstitutional. As was mentioned above, in disputes between the branches, the Court does purport to be performing the strongest form of its settlement function. Insofar as one grants that the branches are to be bound by Supreme Court decisions in circumstances when the Court intends them to be so bound, the resolution of a separation of powers controversy between the branches is as final as it gets. Thus, it would be a mistake to argue that a dispute of the kind at issue here is one that by nature is a political question or would not actually settle the inter-branch dispute.

The classic separation of powers disputes, however, do not come to the Court directly and nakedly as disputes between the President and Congress. They come to the Court through claims by private persons or independent institutional actors who contend that the constitutional structure was intended to allocate power between the branches in a manner that would be protective of their interests. More importantly, they come to the Court through claims by private persons or independent institutional actors who are armed with the statutory authority to make such claims to the Court.

In Myers, the effect of the President asserting his constitutional prerogatives was to terminate the employment of an officer who then sought a remedy for the right that he had lost by virtue of his dismissal. His claim, however, was not simply one of constitutional right. It was a claim for back pay in the court of claims, which presumably rested on a statutory right to make such a claim. ${ }^{96}$ It is not clear, in other words, that barring some due process concern the plaintiff had any personal constitutional right to make the constitutional claim that proved decisive. Similarly, in INS v. Chadha, ${ }^{97}$ the separation of powers controversy arose because an immigrant contended that the separation of powers pro-

94. 272 U.S. 52 (1926).

95. See id. at 117 (relying on the Take Care Clause in part).

96. See id. at 107-08.

97. 462 U.S. 919 (1983). 
tected his interest in not being deported, and he had been afforded a statutory right to make such a claim. ${ }^{98}$

There is no doubt that individuals should not be categorically barred constitutionally from challenging in court the accommodation that the branches may have reached as to the scope of their respective authority. It would be a mistake to conclude, however, that we need such disputes to be resolved in court solely for the sake of clarifying each branch's understanding of the scope of its own authority. They are resolved in court for the benefit of the private parties or independent institutional actors who have been armed with causes of action by Congress for the purpose of permitting them to secure their statutorily conferred entitlements. They are, in this respect, statutory, rather than constitutional suitors absent some independent constitutional cause of action, such as may be secured by the demands of due process, the First Amendment, habeas corpus, or some other personal right that the constitution itself may be understood to confer.

This point is significant. If the judicial resolution of inter-branch disputes were predicated solely on an argument about the need to preserve the institutional interests of the branches, it would be odd to rely on case-by-case adjudication of private disputes for their resolution. It would make far more sense to have the branches simply request the Court to supply an opinion and be done with it. So long as the Supreme Court's doctrine is to be a guide for the scope of the non-enforcement power, however, it is quite clear that this option is not available. Separation of powers questions are often adjudicated in the courts, and their resolution undoubtedly has the consequence of defining the scope of the powers of the respective political branches. This incidental consequence should not be mistaken for a motivating cause. The primary function of adjudicated separation of powers controversies, as Article III's case or controversy requirement makes clear, is to resolve claims of right, statutorily granted or independently conferred by the Constitution, by individuals. ${ }^{99}$

The separation of powers dispute that arises when the President declines to enforce a statute on constitutional grounds, and thereby renders the controversy non-justiciable, is, therefore, necessarily of a different order than those separation of powers disputes that have reached the Court. No person or institution other than the legislature has been legally harmed by the resolution of the power struggle between the President and the Congress or else the case would have been justiciable. The dispute is in this respect internal, though obviously not of exclusive interest, to the two branches in a way that justiciable separation of powers disputes are not.

For that reason, it would be appropriate for these matters to be handled in the same way that other internal separation of powers disputes are handledthrough the to and fro of political struggle. A typical method of resolving such

98. Arguably, the Constitution, pursuant to the habeas corpus clause, required that such judicial review be available. See Suspension and Supremacy, Jurisdiction and Judicial Power: Habeas Corpus After AEDPA and IIRIRA, 98 COLUM. L. REV. 695 (1998).

99. See U.S. CONST. art. III, § 2, cl. 1. 
rough the to and fro of political struggle. A typical method of resolving such internal inter-branch disputes is to make constitutional litigation an option of last resort, rather than routine course. The clearest example of this practice of extra-judicial resolution may be found in the disputes between the President and Congress over claims of executive privilege. These disputes occasionally reach the courts, though none has reached the Supreme Court, but it is expected that they will do so only at the end of a fairly significant degree of inter-branch negotiation and wrangling. ${ }^{100}$ Professor Johnsen elsewhere has well described the practice of accommodation that structures such disputes. ${ }^{101}$ She explains that it serves to permit the two branches to move from typically absolutist positions to more moderate ones as threats and counter-threats mount. Sometimes, moreover, the negotiations even have the quality of productive exchanges. ${ }^{102}$ It would be wrong to idealize this approach to resolution, ${ }^{103}$ but it would equally wrong to presume that it would best be cured through increased litigation.

The accommodation model seems particularly apt here. Except in rare circumstances, a presidential decision not to enforce a measure will itself often represent only the opening gambit in a complicated political negotiation. It will rarely have the degree of finality about it that a decision to enforce would have. The dispute over Section 567 is a good example of this process. The President asserted that he would enforce the statute so as to occasion a justiciable controversy, but he did not actually proceed to terminate any military personnel. His delay was of sufficient length to permit Congress to revisit the constitutional question, and, eventually, to repeal the provision. In this respect, the President could even be said to have exercised the non-enforcement power. Had the President actually terminated some employees, and had the case gone to court and the statute been upheld under deferential review, it is far less certain that a subsequent repeal would have occurred. So long as no employee had been fired, the President could seek a compromise with the Congress. If negotiations with the Congress broke down, the President would then still have been able to enforce the measure, thereby occasioning a justiciable controversy over its constitutionality. A judicial decision to uphold the statute would not at that point be inconsistent with the President's own constitutional judgment; it would instead reflect the very deference to Congress that the President himself, in the end, decided to afford.

To be sure, in some sense, every assertion of the non-enforcement power imposes some burdens on private persons in a way that not every inter-branch fight over executive privilege will. A victim's family who sees an accused let go because a confession was excluded has arguably been harmed by a presidential decision to decline to enforce Section 3501. A member of the Armed Forces

100. See SHANE \& BRUFF, supra note 74, at 182-208.

101. See Dawn Johnsen, Executive Privilege Since United States v. Nixon: Issues of the Motivation \& Accommodation, 83 MiNN. L. REV. 1127 (1999).

102. See id. at 1139-40.

103. See Strauss, supra note 72 , at 124 (criticizing the notion that inter-branch struggle is beneficial). 
who claims to be at greater risk of acquiring an infectious disease arguably has been harmed by a presidential decision to decline to enforce Section 567. A statute that grants funds to churches in connection with the Federal Bureau of Investigation's efforts to stop hate crimes clearly confers direct, tangible benefits on private parties who would be deprived of those benefits if the President were to conclude that the Establishment Clause bans the provision of such funds. All of these injuries would at least arguably constitute "injury in fact" under the technical law of standing, and therefore suffice to permit a plaintiff with a cause of action to bring suit challenging the President-if only Congress were to confer such a cause of action. ${ }^{104}$

It bears emphasis that it would not be wrong in principle for Congress to conclude that the statutory beneficiaries have been harmed by non-enforcement in a manner sufficiently severe as to entitle them to a cause of action. A consequence of making all non-enforcement disputes justiciable through the recognition or creation of new causes of action, however, would be to transfer control of the inter-branch struggle over relative interpretive authority into a case of individual right to be resolved in court at the insistence of a private party. The transformation of inter-branch disputes over the scope of the non-enforcement power into individual claims for entitlements would have the perhaps unintended effect of precluding the branches from engaging in a form of extrajudicial dispute resolution that is familiar in the separation of powers context. It would also have the direct effect of transferring questions of the President's freedom of action from the political arena to the judicial arena, where private parties would have the authority to police the bounds of presidential enforcement discretion. It would be quite difficult to construct a cause of action that would permit such private policing while cabining it in a manner that would not significantly intrude upon the President's exercise of regular enforcement discretion. At a minimum, the courts should be wary of implying a cause of action that could permit the inter-branch dispute to be resolved by the courts at the insistence of a private party. In addition, Congress and the President should not be misled into concluding either that the non-enforcement dispute is one that, in principle, really concerns individual rights rather than the separation of powers, or that separation of powers disputes must be resolved either in court or not at all.

The need for analytical clarity on this point is important because it is not clear that the constitutional scheme would be better if a court were called upon to resolve more inter-branch disputes over interpretive authority. The cases

104. See William A. Fletcher, The Structure of Standing, 98 YALE L. J. 221, 233 (1988). The fact that there are real persons who may claim to be adversely affected by the President's decision to decline to enforce a statute should not be obscured by these technical rules of federal jurisdiction. The President must consider these claims in reaching his substantive constitutional judgment. Of course, these costs of non-enforcement should not count conclusively against its exercise, for the President, insofar as he identifies them, must still weigh them against the costs to his understanding of the Constitution that would follow from enforcement. 
emerging out of the Clinton $v$. Jones ${ }^{105}$ litigation may be problematic less for their substantive holdings than for the fact that they have been decided. It may be that the constitutional structure is best understood to be intentionally opaque on many questions of relative authority between the branches. A consequence of this opacity is that the practical distribution of entitlements that the Constitution confers serves to structure accommodations between the branches even in the absence of judicial resolution.

There also would be structural costs to increasing the judiciary's role in resolving such disputes. The sensitive questions of interpretive authority that disputes over the non-enforcement power raise would likely be resolved in a categorical manner merely by virtue of the Court's own institutional limitations. Such categorical resolution, as has been suggested, might itself be unfortunate because it would preclude a conception of constitutionalism that rests on shared, rather categorical, interpretive authority. In addition, however much it might be the case that the Court should limit its decision solely to an analysis of the relative interpretive authority of the competing branches, it is quite likely that in taking such a case, the Court would venture to inquire into the substantive assessments of each branch's decision. That result would extend the Court's decisional authority in a manner that neither branch should prefer.

There may be particular benefits to extra-judicial, inter-branch negotiation in circumstances where legislation was passed in connection with omnibus legislation and therefore received little sustained consideration by either branch. Such negotiation may cause one or the other branch to change positions on the substantive constitutional question, as happened in connection with Section 567, which Congress repealed following the President's announcement that he believed it to be unconstitutional. Negotiation may also lead the branches to reach accommodations on ameliorative administrative or legislative action that no court could order as a remedy.

More broadly, much of the recent literature for limiting judicial ambition in constitutional interpretation proceeds from an argument that is concerned less with the legitimacy of courts than the costs that judicial review exacts upon the capabilities of extra-judicial interpreters. The argument is one about the consequences, indeed, the difficulties, of attempting to practice constitutional selfgovernment in the shadow of judges. It is an argument that a system of judicial review necessarily affects the capacity of non-judicial actors to perform constitutional self-government, and that such a system affects them, and by extension, the practice itself, adversely. Rather than constraining and disciplining nonjudicial actors to adhere to constitutional limitations, to forswear the exercise of arbitrary power, such a system conditions them to forswear constitutionalism itself, to perceive it as technical lawyers' work, divorced from their own lives,

105. 520 U.S. 681 (1997). 
something that is done to them rather than something that is created, constructed, or ever applied by them. ${ }^{106}$

This critique suggests that judicial review silences others from engaging in a variation of the current court-centered practice of constitutionalism that we would prefer if only we had the courage to permit it to flourish. Or perhaps, more modestly, it suggests at least that judicial review silences others from engaging in a variation of that practice that, whether attractive or not, a proper understanding of constitutional self-government should commit us to prefer. This critique is relevant to the question at issue even if one rejects its more sweeping implications. If we make justiciability the key constraint in the President's non-enforcement power, we are likely to ensure that the constitutional argumentation that results will be confined to the courts, and the briefs that are filed in them.

It must be acknowledged, of course, that one can get carried away with visions of Presidents soberly consulting the Constitution to decide what must be done. In many instances, the constitutional question will depend in large part on technical lawyers' questions that no President can be expected to master, and indeed, perhaps, that, no President should even be expected to master. That said, the more that the non-enforcement power is understood as one that operates without respect to a justiciability constraint, the more likely it is that the constitutional decision to be made will be one that rests on a judgment of high policy rather than technical legal evaluation. That is yet another virtue of a conception of the non-enforcement power that treats it as an exercise of political authority rather than judicial agency. ${ }^{107}$

\section{VI}

\section{CONCLUSION}

The President quite clearly possesses a non-enforcement power in those circumstances where Supreme Court precedent invalidating the relevant statute appears to be directly controlling, if there is no good faith distinction or reason for departing from the principle of stare decisis. But what of the many instances in which a President's constitutional conviction finds no such validation in precedent?

It is important, in such cases, to pay attention to the practical consequences that follow from non-enforcement decisions. It is important as well to develop a way of thinking about the exercise of the non-enforcement power that is re-

106. See MARK Tushnet, TAKing the Constitution Away From the Courts 10-14, 57-71 (1998).

107. Precisely because the type of judgments to be made under the conception of the nonenforcement power set forth here concern questions of high policy-what are the effects of an exclusionary rule, how necessary is a rule precluding HIV-positive personnel from serving in the military?they should be made only by constitutional actors who are positioned to resolve such questions of high policy. Here, I would think that the President and the Attorney General, in consultation with such other constitutional officers as they deemed necessary, would qualify. 
spectful of a constitutional structure that divides authority among institutions of differing capacities. There are clearly occasions when resolution of a constitutional dispute between the political branches over interpretive authority should be performed by a court. An emphasis on justiciability, however, may distort our reasons for thinking this to be the case.

It would be wrong to assume that judicial review is necessary in order to obtain a "correct" resolution of the substantive constitutional question over which the legislature and the executive disagree. Constitutional doctrine often does not supply that kind of answer in the face of a judgment by a competing branch that a certain course of governmental conduct is unconstitutional. The provision of more information to the courts, therefore, will not necessarily lead us closer to the truth. In some respects, an assumption that the provision of more information to the courts will generate better answers will only lead us further away from an exploration of the ways in which the constitutional structure is premised on a more complicated understanding of constitutional meaning.

That more complicated understanding does not assume political actors should simply assert their constitutional convictions as they see fit, and then duke it out in a fight to the death for final authority. As we have seen, the very reasons that suggest that the Court intends for political actors to exercise independent constitutional judgment suggests as well that each of the political branches owes a measure of deference to the constitutional vision of the other. The areas of political action delimited by Justice Jackson as making up the zone of twilight, in which executive power, though not constitutionally vested as exclusive, is nonetheless properly understood to exist independent of congressional authorization, point the way to structuring the content of inter-politicalbranch deference. Justice Jackson's metaphor helps to delimit areas in which a President can act upon his own constitutional convictions with confidence that his constitutional vision is entitled to weight. The metaphor serves to identify those areas in which the President is presumed to be structurally competent to act on the basis of his own, independent judgment.

It is important to emphasize that the decisional areas within the zone of twilight, limited though they may be, happen to track some of our most recent and important non-enforcement dilemmas. They should not be quickly dismissed, therefore, as mere "special," and thus unimportant, cases. The tendency to relegate such cases to a special class involving executive expertise makes them an exception to a general rule of presidential deference to the constitutional convictions of others, and only that. The existence of the contemporary nonenforcement dilemmas, such as those concerning Sections 567 and 3501, however, should warn us away from a tact that marginalizes such cases from the front and center of the non-enforcement discussion. These contemporary dilemmas should suggest, instead, that it is precisely in the zone of twilight that the non-enforcement dilemma is the most real and vexing. In the large zone in which the respective authority of the executive and legislative branches is relatively clear (the debate over the non-enforcement power itself notwithstand- 
ing), it is far less likely that a President will feel sufficiently confident to substitute his constitutional vision for that of Congress. It is rather in the shadow that twilight creates that a President may be expected to take action that he quite uncontroversially would otherwise decline to even contemplate.

It is important, finally, to emphasize that it would be wrong to assume that the only effective way to resolve the inter-branch dispute that executive nonenforcement may occasion is through constitutional litigation. Inter-branch disputes are susceptible to judicial resolution, but there is no requirement that a court supply resolution in cases in which no private party has been legally harmed. Nor is it clear that it would be wise to expand our conception of legal harm so as to make such inter-branch disputes routinely subject to judicial resolution. As the nature of the dispute over the non-enforcement power is, in a deep sense, an internal one over the scope of interpretive authority, litigation should be a dispute resolution option of last, rather than first, resort.

A President will often act wisely in enforcing a statute notwithstanding constitutional misgivings. There are practical reasons, sounding in a proper understanding of the constitutional relationship between the executive and legislative branches, for permitting the Court to pass on the constitutionality of statutes even when the branches do not see the Constitution in the same way. The judgment as to whether to seek such judicial resolution will often not be compelled, however, by limitations on the capacity of non-judicial actors, such as the President, to discern constitutional meaning. Indeed, a commitment to ensuring that the full meaning of constitutional limitations can be uncovered will sometimes justify the exercise of the non-enforcement power even though such action will preclude judicial review. 